\title{
Estimation of bacterial respiration and growth efficiency in the Ross Sea, Antarctica
}

\author{
Craig A. Carlson ${ }^{1, *}$, Nick R. Bates ${ }^{1}$, Hugh W. Ducklow ${ }^{2}$, Dennis A. Hansell ${ }^{1}$ \\ 'Bermuda Biological Station for Research, Ferry Reach, St. George's GE01, Bermuda \\ ${ }^{2}$ Virginia Institute of Marine Science, The College of William and Mary, PO Box 1346, Gloucester Point, Virginia 23062-1346, USA
}

\begin{abstract}
Seawater cultures were conducted in large volume (36 l) gas impermeable tri-laminate bags for the purpose of empirically deriving bacterial growth efficiency (BGE) and carbon conversion factors (CCF) in the south central Ross Sea. This experimental design allowed for concomitant measurements of metabolic reactants (loss of total and dissolved organic carbon [TOC and DOC]) and products (gain of total carbon dioxide $\left[\mathrm{TCO}_{2}\right]$ and bacterial biomass) to be made from a single incubation vessel. Some previous studies have relied on proxy measurements (e.g. $\mathrm{O}_{2},{ }^{3} \mathrm{H}$-thymidine incorporation and cell abundance) to determine BGE and CCF rather than direct carbon measurements. Our experimental design enabled a complete carbon budget to be constructed and eliminated variability associated with normally employed parallel bottle incubations. Utilization of TOC was well balanced by the production of $\mathrm{TCO}_{2}$, in 7 of 8 experiments, validating the use of tri-laminate bags for measuring microbial respiration. In 3 experiments, where $\mathrm{TOC}, \mathrm{DOC}, \mathrm{TCO}_{2}$ and bacterial biovolume were directly measured, carbon mass balance yielded BGE estimates of 12,32 and $38 \%$ and bacterial CCF of 77,95 and

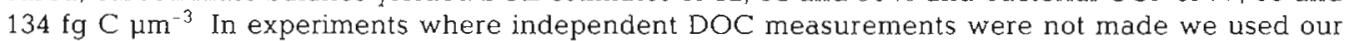
empirically derived CCF values to determine bacterial carbon production and calculated DOC concentrations and BGE for these remaining experiments. The BGE derived from all the bag experiments conducted throughout the austral spring and summer 1995-1997 ranged from 9 to $38 \%$. Our experimental design and carbon mass balance approach could be applied to other aquatic systems to empirically derive the BGE and CCF, factors essential for determining carbon flux through bacterioplankton.
\end{abstract}

KEY WORDS: DOC remineralization - Bacterial respiration $\cdot \mathrm{TCO}_{2} \cdot$ Growth efficiency Carbon conversion factor . Tri-laminate bags $\cdot$ Seawater culture

\section{INTRODUCTION}

The biological remineralization of marine dissolved organic carbon (DOC) occurs predominantly through the single process of oxidation by bacterioplankton (Azam \& Hodson 1977). During the past 2 decades the development of new methodologies to estimate bacterioplankton abundance (Hobbie et al. 1977, Watson et al. 1977) and production (Karl 1979, Fuhrman et al. 1980, Kirchman et al. 1985) have provided a large volume of information regarding heterotrophic microbial activity in a variety of marine habitats (see Ducklow \&

\footnotetext{
•E-mail: ccarlson@sargasso.bbsr.edu
}

Carlson 1992, Ducklow \& Shiah 1993, Karl 1993). However, the majority of these studies has focused solely on bacterial production as a measure of metabolic activity and has disregarded bacterial respiration (Jahnke \& Craven 1995). Bacterial production methods estimate the amount of DOC incorporated into bacterial biomass but do not quantify the amount of DOC metabolized by bacterioplankton. Estimates of bacterial growth efficiency (BGE), the efficiency at which bacterioplankton convert DOC into bacterial biomass, or bacterial respiration, are needed to calculate the total flux of DOC through bacterioplankton.

Specific radioactively labeled compounds have been used to trace the pathway of labile dissolved organic matter (DOM) through bacterioplankton in situ (Wil- 
liams 1970, 1981, Rich et al. 1996). There is, however, a broad continuum of lability found in the bulk DOC pool, with portions of the DOC pool turning over on time scales of hours to days and other portions turning over on time scales of millennia (Bauer et al. 1992, Kirchman et al. 1993, Carlson \& Ducklow 1995, Cherrier et al. 1996). Due to limited analytical capabilities, there are no direct means of measuring the flux of a complex natural DOC compounds to bacterial consumers in situ. Instead, estimates of DOC flux through bacterioplankton are commonly determined by measuring bacterial production and applying a BGE to calculate bacterial carbon demand (Ducklow \& Carlson 1992). In addition, an accurate carbon conversion factor (CCF) is required to convert bacterial cell production measurements, employing ${ }^{3} \mathrm{H}$-thymidine and ${ }^{3} \mathrm{H}$ leucine incorporation, into carbon units. Considerable variability of both BGE (Jahnke \& Craven 1995, Carlson \& Ducklow 1996, del Giorgio et al. 1998) and CCF (see Ducklow \& Carlson 1992) are reported in the literature, therefore it is best to determine these conversion factors empirically for a given system.

Bacterial utilization of DOC and assimilation efficiency was first determined with ${ }^{14} \mathrm{C}$-labeled substrates (Hobbie \& Crawford 1969, Williams 1970, 1981). These experiments yielded assimilation efficiencies of 50 to $95 \%$, but were not considered realistic estimates of BGE because only model compounds were used (Bjørnsen \& Kuparinen 1991, del Giorgio \& Cole 1998). Benner et al. (1988) used ${ }^{14} \mathrm{C}$-labeled refractory macrophyte detritus to determine $\mathrm{BGE}$ and found yields of $\sim 30 \%$. Newell et al. (1981) directly measured the disappearance of natural detrital material and bacterial growth over time and reported a lower BGE of 2 to $37 \%$. More recently, changes in DOC concentrations have been used to derive BGE (Servais et al. 1989, Kirchman et al. 1991, Kroer 1993, Carlson \& Ducklow 1996, Cherrier et al. 1996). Zweifel et al. (1993) and Carlson \& Ducklow (1996) suggested that the further constraint of respiration measurements, in addition to monitoring changes in substrate, would provide more accurate estimates of BGE.

Changes in respiration reactants $\left(\mathrm{O}_{2}\right.$; Williams 1984 , Jensen et al. 1990, Coffin et al. 1993, Biddanda et al. 1994, Daneri et al. 1994) or products (total carbon dioxide, $\mathrm{TCO}_{2}$; Hansell et al. 1995) are often measured as proxies for DOC utilization. Traditionally, bacterioplankton or community respiration studies have been conducted in a series of parallel glass bottles incubated in the dark, where replicate bottles are terminated at various time points throughout an experiment (Williams 1984, Jensen et al. 1990, Coffin et al. 1993, Biddanda et al. 1994, Hansell et al. 1995, Smith \& Kemp 1995). This design is effective for measuring changes in $\mathrm{O}_{2}$ or $\mathrm{TCO}_{2}$, but excludes additional measurements of biological and chemical parameters because the volumes needed would compromise the gas measurements. An additional problem associated with using $\mathrm{O}_{2}$ as a proxy for respiration is the uncertainty of the $\mathrm{O}_{2}: \mathrm{CO}_{2}$ ratio (i.e. respiratory quotient, $\mathrm{RQ}$. Bottle-to-bottle variability and the potential for glass to leach trace metal contaminants (Fitzwater et al. 1982) thereby affecting bacterial growth can also increase experimental error.

Kruse (1993) developed a promising approach for measuring bacterial or community respiration in gas impermeable bags, eliminating the need for multiple vessel incubations. Here we expanded upon Kruse's work by conducting seawater cultures in large volume (12 to $36 \mathrm{l}$ ) incubation bags constructed of a tri-laminate material of polypropylene, aluminum foil and polyethylene and directly measured the covariation of $\mathrm{TCO}_{2}$, total organic carbon (TOC), DOC and bacterial biovolume. We decided to measure $\mathrm{TCO}_{2}$ directly, thus avoiding the uncertainties associated with the $R Q$. Direct measurements of all these variables allowed us to construct a carbon budget. The objectives of this study were: (1) to evaluate the use of large volume incubation bags for conducting bacterial respiration measurements in the Ross Sea, Antarctica; (2) to directly measure chemical reactants (DOC) and respiration products $\left(\mathrm{TCO}_{2}\right)$ and use carbon mass balance to estimate BGE independent of bacterial measurements; (3) to compare changes of these chemical properties with bacterial biovolume to further constrain the CCF of Ross Sea bacterioplankton; and (4) to place our estimates in the context of other empirically derived BGEs and CCFs from the Southern Ocean. This experimental design and carbon mass balance approach could be applied to other aquatic systems.

\section{METHODS}

Conceptual background and calculations. BGE is determined empirically by measuring changes in concentrations of metabolic reactants (loss of DOC and oxygen) or products (gain of $\mathrm{CO}_{2}$ and bacterial biomass) within a closed system. In this study seawater cultures were conducted in gas impermeable tri-laminate bags, where direct measurements of $\mathrm{TOC}_{1} \mathrm{TCO}_{2}$ and DOC were sampled at regular intervals and used to solve for BGE via mass balance. The changes in TOC (DOC plus any particulate matter present in the $0.8 \mu \mathrm{m}$ filtrate), $\mathrm{TCO}_{2}$ (bacterial respiration of organic carbon to $\mathrm{CO}_{2}$ ) and $\mathrm{DOC}\left(\triangle \mathrm{TOC}, \triangle \mathrm{TCO} \mathrm{C}_{2}\right.$ and $\triangle \mathrm{DOC}$, respectively) through time were determined as the difference between initial concentrations and concentrations measured at succeeding time points. In some cases an initial temporal lag was observed in which 
there were no measurable changes in $\mathrm{TOC}_{3} \cdot \mathrm{TCO}_{2}$ and DOC concentrations during the first few time points. A mean concentration for each variable's lag phase was used as the initial value. The sense of these changes are reflected in the associated sign. For example the sign would be positive for $\triangle \mathrm{TCO}_{2}$ and negative for both $\triangle \mathrm{DOC}$ and $\triangle \mathrm{TOC}$.

Because $\triangle T O C$ is the balance between POC increase and DOC decrease throughout the incubation we attributed the observed net decrease in TOC ( $\triangle \mathrm{TOC})$ to bacterial respiration. Thus, we hypothesized that $-1 \times \triangle \mathrm{TOC}$ and $\Delta \mathrm{TCO}_{2}$ would yield comparable changes in bacterial respiration $(\triangle B R)$. The change in DOC can be expressed as:

$$
-\triangle \mathrm{DOC}=\triangle \mathrm{POC}+\triangle \mathrm{BR}
$$

where $\triangle \mathrm{POC}$ represents the change in particulate organic carbon (POC) resulting from the conversion of $D O C$ to bacterial biomass and $\triangle B R$ represents the amount of DOC respired to $\mathrm{CO}_{2}$. POC was not measured directly in this study; instead, $\triangle \mathrm{POC}$ was calculated as:

$$
\triangle \mathrm{POC}=-1 \times(\triangle \mathrm{DOC}+\Delta \mathrm{BR})
$$

where $\triangle \mathrm{POC}$ was derived from the mass balance of $\triangle \mathrm{DOC}$ and $\triangle \mathrm{BR}$. When possible, both estimates of $\triangle B R$ were utilized to generate $\triangle \mathrm{POC}$ values for each time point where corresponding $\mathrm{TOC}, \mathrm{DOC}$, and $\mathrm{TCO}_{2}$ measurements were made. To remove bias associated with either $B R$ estimate we took the mean $\triangle \mathrm{POC}$ value of the 2 methods for each time point. In the cases where bacterial POC could not be determined by mass balance due to lack of DOC data (Ross Sea Polynya Project [RSPP] experiments) it was derived from the product of bacterial biovolume multiplied by an empirically derived CCF (see below).

The efficiency at which bacterioplankton convert DOC into bacterial biomass, BGE, can be expressed by the following formulae:

$$
\mathrm{BGE}=\Delta \mathrm{POC} /-\triangle \mathrm{DOC} \times 100 \%
$$

or, by inserting Eq. (1) into Eq. (3),

$$
\mathrm{BGE}=\triangle \mathrm{POC} /(\triangle \mathrm{POC}+\Delta \mathrm{BR}) \times 100 \%
$$

Based on these equations we derived BGE by property-property linear regression of measured and calculated variables as described in Bjørnsen \& Kuparinen (1991). This approach allowed us to derive BGE from a maximum number of data points for each experiment. The slopes of the linear regressions of $\triangle \mathrm{POC}$ versus $-\triangle D O C$ or $\triangle P O C+\triangle B R$ equaled $B G E$. Based on the criteria described in Sokal \& Rohlf (1995) principal axis Model II regression was used to determine BGE.

CCFs were also derived for experiments where TOC, $\mathrm{TCO}_{2}$ and DOC were all measured directly. CCFs were determined from the slopes of the geometric mean Model II linear regression (Sokal \& Rohlf 1995) of $\triangle \mathrm{POC}$ versus bacterial biovolume as described in Bjornsen \& Kuparinen (1991).

All statistical analyses were performed with Matlab (Mathworks Inc, Natick, MA, USA) or Statview 4.5 (Abacus Concepts, Inc., Berkeley, CA, USA). The standard error of CCF and BGE estimates was determined as the standard error of the slope from each of the Model II regressions. In the cases where variables were derived the standard error was propagated through the equation according to Bevington (1969).

Seawater culture preparation. These experiments were conducted during several expeditions aboard the Research Vessel-Ice Breaker (RVIB) 'Nathaniel B. Palmer' in the Ross Sea, Antarctica. The work was conducted as part of the RSPP and the US Joint Global Ocean Flux Study (JGOFS) Antarctic Environment Southern Ocean Process Study (AESOPS). Both projects occupied the same region of the southern Ross Sea in different years. Seawater was collected from several stations along the $76^{\circ} 30^{\prime} \mathrm{S}$ transect line during cruises in December 1995, January 1996, October 1996, and January 1997 (Table 1). Water was collected from depths between 5 and $15 \mathrm{~m}$ via 301 Niskin bottles suspended on a hydrowire or GoFlo bottles (General Oceanics) on the Moss Landing Marine Laboratory's trace metal clean CTD (conductivity, temperature, depth probe) rosette. Upon recovery, water was gravity filtered through a $0.8 \mu \mathrm{m}$ Costar Membra-Fil filter held in a $142 \mathrm{~mm}$ all plastic filtration rig. The filtration rig was attached to the Niskin bottle via silicone tubing and the filtrate was collected into polycarbonate carboys. All carboys, filtration devices and tubing were washed in $5 \% \mathrm{HCl}$ and rinsed with copious amounts of Nanopure water prior to each experiment.

The Costar Membra-Fil filters provide a high flow rate and are relatively gentle to cells during gravity filtration (Carlson \& Ducklow 1996). The $0.8 \mu \mathrm{m}$ filter effectively removed eukaryotic cells including bacteriovores while allowing a significant fraction of the bacterioplankton to pass. Untreated filters initially leach a measurable amount of DOC, thereby requiring thorough flushing with at least $2 \mathrm{I}$ of Nanopure water and another $0.5 \mathrm{l}$ of sample water prior to collecting the filtrate (Carlson \& Ducklow 1996). Filters were changed after every $5 \mathrm{l}$ of sample to minimize DOC release from POC retained on the filter.

The RSPP bag 4 experiment (Table 1) was set up differently in that 201 of whole surface seawater was incubated in a polycarbonate carboy in an on-deck incubator for $10 \mathrm{~d}$. Following initial incubation seawater was gravity filtered through a $0.8 \mu \mathrm{m}$ filter, placed into a gas impermeable bag and incubated in the dark, as described above. The objective was to introduce a 
Table 1. Experimental parameters for Ross Sea bag experiments from 1995-1997. Depth refers to the depth water was collected for seawater culture experiment. Chl a, POC and DOC represent in situ concentrations at the time water was collected for the experiment. TOC initial represents TOC concentration (DOC plus POC) present in the $0.8 \mu \mathrm{m}$ seawater culture filtrate. DOC initial is concentration of organic carbon present in the seawater culture at time zero after passing through an additional GF/F filtration step. Values within parentheses are standard errors of the respective values. -: data not available. RSPP: Ross Sea Polynya Project, AESOPS: Antarctic Environment Southern Ocean Process Study

\begin{tabular}{|c|c|c|c|c|c|c|c|c|c|c|c|}
\hline \multirow[t]{2}{*}{$\operatorname{Expt}^{\mathrm{a}}$} & \multirow[t]{2}{*}{ Position } & \multirow[t]{2}{*}{ Start date } & \multirow{2}{*}{$\begin{array}{l}\text { Depth } \\
\text { (m) }\end{array}$} & \multicolumn{3}{|c|}{ In situ conditions } & \multicolumn{3}{|c|}{ Culture conditions } & \\
\hline & & & & $\begin{array}{c}\mathrm{Chl} a \\
\left(\mu \mathrm{g} \mathrm{l}^{-1}\right)\end{array}$ & $\begin{array}{c}\text { POC } \\
(\mu \mathrm{MC})\end{array}$ & $\begin{array}{c}\mathrm{DOC} \\
(\mu \mathrm{MC})\end{array}$ & $\begin{array}{c}\text { TOC } \\
\text { initial } \\
(\mu \mathrm{MC})\end{array}$ & $\begin{array}{c}\text { DOC } \\
\text { initial } \\
(\mu M C)\end{array}$ & $\begin{array}{c}\mathrm{TCO}_{2} \\
\text { initial } \\
(\mu \mathrm{M} C)\end{array}$ & $\begin{array}{l}\text { temp. } \\
\left({ }^{\circ} \mathrm{C}\right)\end{array}$ & $\begin{array}{l}\text { duration } \\
\text { (d) }\end{array}$ \\
\hline RSPP bag 1 & $76.50^{\circ} \mathrm{S} 177.69^{\circ} \mathrm{E}$ & $24 \operatorname{Dec} 95$ & 5 & 8.6 & 37.4 & $43.8(0.4)$ & $60.1(0.3)$ & - & $2155.6(0.5)$ & 0 & 11 \\
\hline RSPP bag $12^{\circ} \mathrm{C}$ & $76.50^{\circ} \mathrm{S} 177.69^{\circ} \mathrm{E}$ & $24 \operatorname{Dec} 95$ & 5 & 8.6 & 37.4 & $43.8(0.6)$ & $56.4(0.7)$ & - & $2162.0(0.5)$ & 2 & 11 \\
\hline RSPP bag 2 & $76.50^{\circ} \mathrm{S} 164.96^{\circ} \mathrm{E}$ & 29 Dec 95 & 10 & 3.5 & 25.3 & $47.8(0.4)$ & $52.4(0.6)$ & - & $2129.4(0.3)$ & 0 & 10 \\
\hline RSPP bag 4 & $76.50^{\circ} \mathrm{S} 168.47^{\circ} \mathrm{E}$ & 7 Jan 96 & 15 & 3.1 & 79.0 & $54.4(0.7)$ & $59.7(0.6)$ & - & $2073.5(0.2)$ & 0 & 8 \\
\hline AESOPS I bag 1 & $76.50^{\circ} \mathrm{S} 179.98^{\circ} \mathrm{E}$ & 19 Oct 96 & 10 & 0.1 & 1.9 & $41.1(0.6)$ & $50.4(0.6)$ & $50.3(0.5)$ & $2222.3(0.5)$ & -1 & 16 \\
\hline AESOPS I yeast ${ }^{\circ}$ & $76.50^{\circ} \mathrm{S} 179.98^{\circ} \mathrm{E}$ & 19 Oct 96 & 10 & 0.1 & 1.9 & $41.1(0.8)$ & $57.7(0.6)^{\circ}$ & $57.6(0.7)$ & $2241.7(0.4)$ & -1 & 14 \\
\hline AESOPS II bag 1 & $76.50^{\circ} \mathrm{S} 176.00^{\circ} \mathrm{E}$ & $17 \mathrm{Jan} 97$ & 10 & 6.1 & 86.6 & $61.6(0.8)$ & $75.3(0.4)$ & $72.3(0.4)$ & 2073.0 & 0 & 15 \\
\hline AESOPS II bag 2 & $76.50^{\circ} \mathrm{S} 176.00^{\circ} \mathrm{E}$ & $23 \operatorname{Jan} 97$ & 10 & 4.8 & 60.8 & $66.7(0.4)$ & $69.8(0.7)$ & $68.9(0.6)$ & $2062.5(0.2)$ & 0 & 15 \\
\hline
\end{tabular}

fresh suite of DOC compounds for bacterioplankton to grow on. The filtrate for the AESOPS I yeast experiment (Table 1) was set up as described above but amended with $10 \mu \mathrm{M} \mathrm{C}$ in the form of yeast extract with the objective of enhancing bacterial growth during late winter/early spring conditions and testing the experimental design.

Tri-laminate bags. Incubation bags were constructed of a tri-laminate material composed of polypropylene, aluminum foil and polyethylene (LPS Industries Inc., Newark, NJ, USA). The material is used in the food packing industry because of its opaque, non-toxic and gas impermeable qualities. The construction of the bag included 2 ports, one for sampling and one for bleeding air while the bag was being filled. To construct the ports two $3 / 8$ " $(-9.5 \mathrm{~mm})$ holes were cut into opposite ends of the bag. A nylon-barbed fitting was threaded, in this order, through a Teflon washer, a Teflon-coated silicone septum, the tri-laminate material, another Teflon-coated septum and finally screwed into a Teflon nut. When tightened the combination of washers and septa made the fittings gas- and watertight. The bags were sealed with an Impulse heat sealer (TEW Electric Heating Company). All bags were filled with $5 \% \mathrm{HCl}$ and soaked for several hours, then rinsed with at least $2 \mathrm{l}$ of Nanopure water prior to filling.

The tri-laminate bags were placed in an incubation bath then filled with the $0.8 \mu \mathrm{m}$ filtrate. The filtrate flowed from the collection carboy into the bag via silicone tubing. Caution was taken to minimize the introduction of air into the bag during filling. Once filled, one of the silicone tubes was clamped shut and the bag was squeezed to purge any air that may have initially been trapped. After purging, both ports were clamped shut. The final volume of the bags ranged from 12 to 361 of filtrate. The bags were submerged in an incubation bath, left to acclimate to a preset temperature for 2 to $3 \mathrm{~h}$, then purged once more before sampling commenced. The water baths were either flowing seawater aquaria or large coolers filled with surface water and placed in environmental rooms or incubators and maintained at the desired temperatures (Table 1). A $1 \mathrm{~m}$ long silicone tube, connected to a sample port, hung outside of the incubation bath and below the center of gravity of the bag so that when the clamps on the sampling tube were released, sample was drawn by siphon. All experiments were subsampled at varying intervals of 0.5 to $2 \mathrm{~d}$.

Bacterial biomass and biovolume. Bacterial abundance and biovolume were determined microscopically, following US JGOFS Protocols (UNESCO 1994). Samples were preserved with particle-free $25 \%$ glutaraldehyde (final concentration $1 \%$ ) and stored at $4^{\circ} \mathrm{C}$ for less then $48 \mathrm{~h}$ until slide preparation. Samples were filtered through $0.2 \mu \mathrm{m}$ black polycarbonate filters and stained with acridine orange (final concentration $0.005 \%$; Hobbie et al. 1977). Bacterial biovolumes were estimated using a Zeiss Axiophot epifluorescence microscope and a video image analysis system (Bjornsen 1986a, Carlson \& Ducklow 1996). We used blue excitation ( 450 to $490 \mathrm{~nm}$ ) from a $200 \mathrm{~W}$ mercury lamp, with a $510 \mathrm{~nm}$ beam splitter and a $520 \mathrm{~nm}$ emission filter. Filtration volumes were adjusted to deposit ca 15 to 20 cells within the $24 \times 24 \mu$ m camera field viewed at $1000 \times$. Sufficient video images were acquired on each 
slide to yield about 300 to 600 measurements of individual cells. Apparent cell volume was derived using an algorithm from image analysis estimates of cell axes, area and perimeter, which avoids large errors resulting from cubing linear dimensions (Ducklow et al. 1992). The standard error associated with mean cell volume and bacterial abundance were 5 and $6 \%$ of the means of each respective measurement.

Experiments were conducted in 1997 to assess bacterial growth on the bag's inner wall. Pieces of the trilaminate material were cut from the bag at the end of the experiment and were stained with acridine orange. The piece of bag material was then mounted on a slide and counted immediately.

TOC and DOC. TOC measured for water drawn from the seawater cultures refers to the total (particulate + dissolved) organic carbon ( $\mu \mathrm{MC}$ ) present within the $0.8 \mu \mathrm{m}$ culture medium. Samples for TOC were collected directly from the sampling tube into precombusted $40 \mathrm{ml}$ glass vials with Teflon-coated silicone septa. DOC samples were generated by first removing particulate (bacterial) carbon. In the RSPP experiments samples for DOC analyses were filtered via syringe filtration through $25 \mathrm{~mm} \mathrm{GF/F} \mathrm{filters;} \mathrm{however} \mathrm{result-}$ ing data were variable and often contaminated, rendering the data unreliable. Subsequent filtration tests during AESOPS cruises demonstrated that in-line gravity filtration through a precombusted $G F / F$ was the cleanest method when compared to syringe filtration through GF/F, $0.2 \mu \mathrm{m}$ polycarbonate, $0.2 \mu \mathrm{m}$ cellulose ester, or $0.2 \mu \mathrm{m}$ aluminum oxide filters. All of the $0.2 \mu \mathrm{m}$ syringe filters leached measurable amounts of DOC (4 to $20 \mu \mathrm{M}$ ) and could potentially contaminate DOC samples. We did not use these data. Retention efficiency of bacterial cells on the GF/F filters was tested in 1997 by comparing direct counts of filtered and unfiltered water. These experiments demonstrated gravity filtration through a GF/F filter retained $~ 80 \%$ of the bacterioplankton in early stages of the cultures and increased in retention efficiency (i.e. 90 to $98 \%$ retained) in $\log$ and stationary growth phase (data not shown). This increased retention was largely attributed to the size and density to which the cells grew during latter stages of the experiment. Kroer (1993) and Kähler et al. (1997) have also reported similar cell retention on GF/F filters.

All TOC and DOC samples were analyzed by a high temperature combustion (HTC) method using a homemade instrument. We redesigned the HTC systems previously used by Carlson \& Ducklow (1996) and Hansell \& Waterhouse (1996), resulting in a high precision system (mean standard error $\pm 0.6 \mu \mathrm{M} \mathrm{C}$ ) and increased day-to-day stability. Ultra high purity $\mathrm{O}_{2}$ flowed through the machine at $175 \mathrm{ml} \mathrm{min}^{-1}$. Samples were acidified $\left(10 \mu \mathrm{l}\right.$ of $85 \% \mathrm{H}_{3} \mathrm{PO}_{4}$ per $10 \mathrm{ml}$ of sam- ple) and sparged with $\mathrm{CO}_{2}$-free oxygen for at least $10 \mathrm{~min}$ to remove inorganic carbon. One-hundred $\mu \mathrm{l}$ of sample was injected manually through a septumless port into the quartz combustion tube packed with $\mathrm{Pt}$ gauze (Aldrich), $7 \% \mathrm{Pt}$ on alumina catalyst (Shimadzu), Sulfix (Wako Pure Chemical Industries, Inc.) and $\mathrm{CuO}$ wire (Leeman Labs). The furnace was divided into 2 zones. The Pt gauze and Pt beads were heated to $800^{\circ} \mathrm{C}$ and the remaining packing material was heated to $600^{\circ} \mathrm{C}$. The resulting $\mathrm{CO}_{2}$ flowed through 2 water traps and a final copper halide trap then was detected with a LiCor $6252 \mathrm{CO}_{2}$ analyzer. The signal was integrated with chromatographic software (Dynamax Macintegrator I version 1.3; Rainin Inst.).

Extensive conditioning of the combustion tube was essential to minimize the machine blank. The system blank was assessed with ampulated low carbon waters (LCW) that have been referenced against blank water provided by Dr Jonathan Sharp for the 1994 DOC community intercomparison program (Sharp 1994). The system response was standardized daily with a 4 -point calibration curve of glucose solution in LCW. Deep Sargasso seawater $(>2000 \mathrm{~m}$ ) served as a reference standard. To ensure optimal stability of the HTC analyzer all samples were analyzed ashore at the Bermuda Biological Station for Research (BBSR). In order to avoid the small error associated with instrumental day-to-day variability, all samples generated from 1 experimental treatment were analyzed on the same day and systematically checked against LCW and deep reference seawater. The error reported for TOC and DOC concentrations is the standard error of 4 to 6 replicate injections.

$\mathrm{TCO}_{2}$. Duplicate $500 \mathrm{ml}$ samples were collected in Pyrex bottles with ground glass stoppers. Bacterial respiration was halted with the addition of $100 \mu \mathrm{l}$ of saturated $\mathrm{HgCl}_{2}$. Stoppers were lubricated with Apiezon L grease, fastened shut and stored until analysis back at the BBSR. This storage procedure preserves the integrity of the sample for at least 1 yr (Bates unpubl. data). Concentrations of $\mathrm{TCO}_{2}$ were determined by gas extraction and coulometric detection, similar to the method described by Johnson et al. $(1985,1987,1993)$ and Bates et al. (1996). A SOMMA (Single Operator Multiparameter Metabolic Analyzer; Johnson et al. 1993) was used to control the pipetting and extraction of a seawater sample. During this procedure a calibrated volume of seawater was acidified, converting $\mathrm{HCO}_{3}{ }^{-}$and $\mathrm{CO}_{3}{ }^{2-}$ to free $\mathrm{CO}_{2}$. The evolved $\mathrm{CO}_{2}$ was carried by an inert gas $\left(\mathrm{N}_{2}\right)$ to a coulometer cell where it was absorbed by a solution containing ethanolamine, dimethylsulfoxide and a thymolphthalein indicator. Current generated by the titration of $\mathrm{CO}_{2}$ was related by the Faraday constant to the moles of $\mathrm{CO}_{2}$ absorbed 
by the solution (Johnson et al. 1993). The measurement is calibrated with known volumes of pure $\mathrm{CO}_{2}$ gas (Wilke et al. 1993). Precise (mean standard error $\pm 0.3 \mu \mathrm{mol} \mathrm{kg}{ }^{-1}$ ) measurements of $\mathrm{TCO}_{2}$ allowed us to monitor small changes in $\mathrm{TCO}_{2}$ during incubations. Samples from each seawater culture experiment were analyzed on the same day using the same coulometer cell and solutions.

Assessment of experimental design. A principal assumption was that the tri-laminate bags were gas impermeable. To test this assumption an experiment was conducted at the BBSR in which approximately 81 of Sargasso seawater were placed into a tri-laminate bag, as described above, and fixed with $2.0 \mathrm{ml}$ of saturated $\mathrm{HgCl}_{2}$. The partial pressure of $\mathrm{CO}_{2}$ $\left(p \mathrm{CO}_{2}\right)$ in the seawater within the bag was approximately $50 \mu \mathrm{atm}$ higher than air providing a potential gradient for gas exchange. The bag was placed in an incubation bath ( $p \mathrm{CO}_{2}$ equilibrated with atmosphere) at in situ temperature $\left(26^{\circ} \mathrm{C}\right)$ and allowed to incubate for $10 \mathrm{~d}$. Replicate samples were drawn for $\mathrm{TCO}_{2}$ samples at the beginning and at the end of the incubation. This control experiment conducted in a $\mathrm{CO}_{2}$ gradient was used to test for gas exchange across the bag material.

\section{RESULTS}

\section{Initial conditions}

These experiments were all conducted in the southern Ross Sea during various phases of phytoplankton blooms, which were dominated by the colonial haptophyte Phaeocystis antarctica. AESOPS I experiments were conducted during pre-bloom conditions where chlorophyll a (chl a), POC and DOC concentrations were all at winter-time background level (Table 1). All other experiments were conducted during an active phytoplankton bloom period where initial in situ chl a concentrations were greater than $3 \mu \mathrm{g} \mathrm{l}^{-1}$ and suspended POC concentrations within 50 to $140 \%$ of the surface water DOC concentrations (Table 1). The elevated POC load measured in the water column coincided with the production of large mucilaginous colonies of $P$. antarctica. When large volumes of water were filtered this mucilage material clogged filters rapidly and could result in the passage of a small fraction of POC through the filter and release of $D O C$ from the POC retained on a filter (Carlson et al. in press). Despite all precautions taken, such as copious rinsing of filters, gentle gravity filtration, and changing filters every $5 \mathrm{l}$, TOC within the culture and DOC was enhanced 3 to $18 \mu \mathrm{M} \mathrm{C}$ above in situ concentrations (Table 1).

\section{Assessment of experimental design \\ Gas exchange and abiotic effects}

The assumption that the tri-laminate bags were gas impermeable (on the $\mu \mathrm{M}$ scale) was tested by measuring changes in $\mathrm{TCO}_{2}$ concentrations in a bag in which Sargasso seawater had been killed with $\mathrm{HgCl}_{2}$. The initial and final time points of $\mathrm{TCO}_{2}$ were 2032.6 \pm 0.3 and $2032.9 \pm 0.3 \mu \mathrm{M} \mathrm{C}_{\text {, respectively, demonstrating }}$ no significant change in $\mathrm{TCO}_{2}$ throughout the $10 \mathrm{~d}$ in a $p \mathrm{CO}_{2}$ gradient of $50 \mu \mathrm{atm}$. These results indicate that the tri-laminate material was a good barrier to gas exchange.

Minimal bacterial growth was observed in the AESOPS I bag 1 experiment in which no measurable change in $\mathrm{TCO}_{2}$ production or TOC consumption was observed over $16 \mathrm{~d}$ (Fig. 1). These results indicate that those abiotic factors such as gas exchange or net adsorption or leaching of organic matter to and from the bag walls were insignificant on the scale of resolution of our analysis. In parallel seawater culture experiments bacterial growth in tri-laminate bags was comparable to growth observed in polycarbonate carboys (data not shown), indicating that the tri-laminate material did not leach anti-microbial agents.

\section{Wall growth}

The total area of tri-laminate material used to make a $36 \mathrm{l}$ bag was $\sim 0.7 \mathrm{~m}^{2}$. In 2 experiments conducted in December 1997, cells attached to the inner wall of the bag were enumerated. The attached cell count equaled 2.6 and $3.5 \times 10^{8}$ cells $\mathrm{m}^{-2}$. The average cell density at the end of all the growing seawater cultures

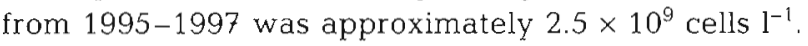

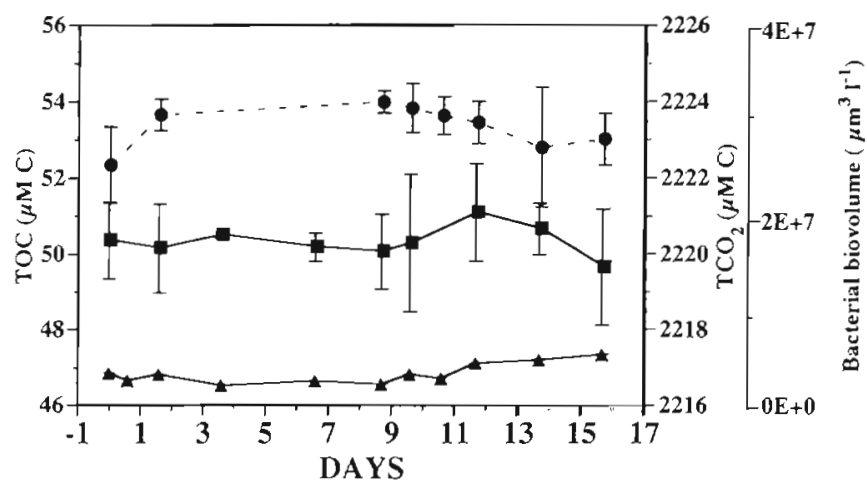

Fig. 1 AESOPS I bag 1 experiment conducted in October 1995. Concentration of total carbon dioxide $\left(\mathrm{TCO}_{2}\right)(\bullet)$, total organic carbon (TOC) ( $\mathbf{n}$ ) and bacterial biovolume (\$) during a $16 \mathrm{~d}$ incubation. Error bars refer to standard error 
At least $10 \mathrm{l}$ of seawater remained in the bag until the last time point for most large volume experiments. This means approximately $2.5 \times 10^{10}$ free living cells were present in a bag at the end of a typical experiment. We estimate that attached bacteria contribute approximately 1 to $2 \%$ of the total bacterial counts in the bag at the end of an experiment.

\section{Evidence of mass balance}

Central to the design of the bag experiments was the assumption that removal of TOC would be accounted for by a concurrent increase in $\mathrm{TCO}_{2}$ concentrations. We assumed abiotic processes such as adsorption or leaching of DOC to and from the bag's wall would be minimal and that the decrease in TOC concentration during the incubations would result from biological respiration. To test this assumption $\triangle \mathrm{TOC}$ and $\triangle \mathrm{TCO}_{2}$ were calculated for each time point in all the experiments conducted from 1995-1997 where concurrent TOC and $\mathrm{TCO}_{2}$ measurements were made. The increase in $\mathrm{TCO}_{2}$ was linearly regressed against the decrease in TOC using Model II principal axis regression. With the exception of 1 experiment (AESOPS I yeast treatment), the 2 variables were well balanced over the course of the incubations, with slopes ranging from -0.94 to -1.06 (Fig, 2). This highly correlated inverse relationship between $\triangle \mathrm{TOC}$ and $\triangle \mathrm{TCO}_{2}$ indi-

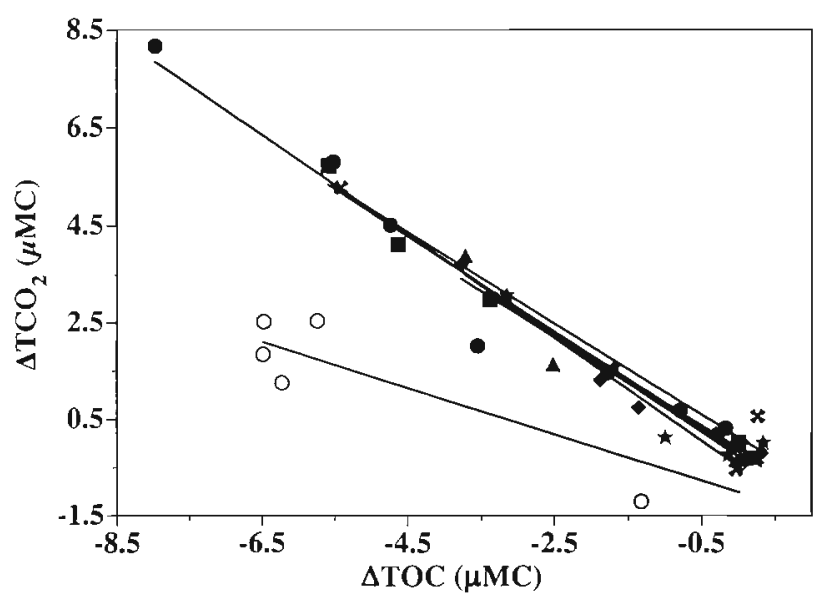

Fig. 2. Property-property plot of $\triangle \mathrm{TCO}_{2}$ and $\triangle \mathrm{TOC}$ for every time point where corresponding measurements were made for all bag experiments from 1995-1997. Lines represent slope of Model II principal axis regression for each experiment. The equation for each regression is as follows: RSPP bag $1(\mathbf{\square}), f(x)=-0.98 x-0.11, r^{2}=0.98$; RSPP bag $12^{\circ} \mathrm{C}(\boldsymbol{*})$, $f(x)=-0.94 x-0.13, r^{2}=0.95 ;$ RSPP bag $2(\Lambda), f(x)=-1.06 x-$ $0.48, r^{2}=0.94 ;$ RSPP bag $4(\bullet), f(x)=-0.95 x-0.18, r^{2}=0.96$; AESOPS I yeast $(0), f(x)=-0.47 x-1.01, \mathrm{r}^{2}=0.8$; AESOPS II bag $1(\bullet), f(x)=-1.02 x-0.27, \mathrm{r}^{2}=0.95$; AESOPS II bag $2(\star)$, $f(x)=-0.94 x-0.09, r^{2}=0.91$ cated that respiration and $\triangle \mathrm{TOC}$ were coupled. Bacteriovore abundances were minimal throughout the incubations and we assumed that bacterial remineralization of organic material was responsible for the great majority of the observed changes. These results confirm that either $\triangle \mathrm{TCO}_{2}$ or $-1 \times \Delta \mathrm{TOC}$ can be used as an index of $\triangle B R$.

In the AESOPS I yeast experiment, the relationship between $\triangle \mathrm{TCO}_{2}$ and $\triangle \mathrm{TOC}$ diverged significantly from the regression line of all other experiments (Fig. 2). We do not know the reason for this uncoupling. Possibilities include a potential tear in the aluminum foil of the bag, $\mathrm{TCO}_{2}$ samples compromised during storage and/or a portion of the yeast extract DOM adsorbed to the walls of the bag.

\section{Bacterial growth}

Following an initial lag of 0 to $7 \mathrm{~d}$ cell abundance increased exponentially in all experiments except AESOPS I bag 1 (Fig. 1) and reached a stationary phase of growth 6 to $11 \mathrm{~d}$ after the initiation of the culture (Tables 2 \& 3). Mean cell volume generally increased throughout the incubation and ranged from 0.052 to $0.195 \mathrm{\mu m}^{3}$, except for the yeast extract amended experiment (AESOPS I yeast), which ranged from 0.037 to $0.331 \mu^{3}$. Some experiments demonstrated a decrease in cell volume after the stationary phase was reached; however, in most experiments cell abundance remained relatively constant during the stationary phase through to the end of the incubations (Tables 2 \& 3). All cultures which demonstrated measurable changes in bacterial abundance and mean cell volume also produced time varying changes in $\mathrm{TCO}_{2}$ production, TOC and DOC consumption (when measured; Tables $2 \& 3$ ). Fig. 3 is an example of the general trends observed in those bag experiments with growing bacterioplankton. In some experiments the chemical parameters continued to change even when a stationary phase of growth was reached towards the end of the incubation (Fig. 2, Tables 2 \& 3). Ducklow et al. (1999, in this issue) present, in a companion paper, a detailed analysis of bacterial growth dynamics for several of the experiments presented here and other seawater cultures conducted in the southern Ross Sea.

\section{Bacterial conversion factors}

Carbon conversion factors

To calculate CCF, it was first necessary to derive estimates of $\triangle P O C$ throughout the incubations. POC was not directly measured, due to limited sample volume, 
Table 2. Bag experiments conducted during AESOPS cruises, 1996-1997. Values in parentheses are standard error

\begin{tabular}{|c|c|c|c|c|c|c|c|}
\hline Expt & Day & $\begin{array}{l}\text { Mean cell volume } \\
\qquad\left(\mu^{3}\right)\end{array}$ & $\begin{array}{l}\text { Cell abundance } \\
\left(10^{8} \text { cells } \mathrm{l}^{-1}\right)\end{array}$ & $\begin{array}{l}\triangle \mathrm{TCO}_{2} \\
(\mu \mathrm{MC})\end{array}$ & $\frac{\Delta \mathrm{DIC}}{(\mu \mathrm{MC})}$ & $\begin{array}{l}\triangle \mathrm{DOC} \\
(\mu \mathrm{MC})\end{array}$ & $\begin{array}{c}\triangle \mathrm{POC} \\
(\mu \mathrm{MC})\end{array}$ \\
\hline \multirow[t]{10}{*}{ AESOPS I yeast } & 0.0 & $0.044(0.002)$ & $0.8(0.1)$ & $0.0(0.6)$ & $-0.4(0.8)$ & $0.1(0.4)$ & $-0.1(0.8)$ \\
\hline & 0.6 & $0.037(0.002)$ & $0.8(0.1)$ & - & - & $0.2(0.6)$ & - \\
\hline & 1.6 & $0.038(0.002)$ & $0.8(0.1)$ & - & $0.4(0.6)$ & $0.2(0.4)$ & - \\
\hline & 3.6 & $0.035(0.002)$ & $0.8(0.1)$ & $0.0(0.5)$ & - & $-0.3(0.3)$ & $0.2(0.5)$ \\
\hline & 6.6 & $0.038(0.002)$ & $0.8(0.1)$ & $-0.2(0.8)$ & - & $-0.2(0.5)$ & $0(0.6)$ \\
\hline & 8.7 & $0.068(0.003)$ & $0.8(0.1)$ & $-1.3(0.8)$ & $-1.2(0.5)$ & $-1.7(0.7)$ & $0.5(1.0)$ \\
\hline & 9.6 & $0.191(0.010)$ & $0.9(0.1)$ & $-6.3(1.0)$ & $2.5(1.0)$ & $-6.8(0.3)$ & $0.4(1.0)$ \\
\hline & 10.6 & $0.331(0.017)$ & $1.7(0.1)$ & $-6.2(0.2)$ & $1.2(0.6)$ & $-7.1(0.4)$ & $0.9(0.4)$ \\
\hline & 11.7 & $0.245(0.013)$ & $4.2(0.3)$ & - & $4.9(0.5)$ & - & - \\
\hline & 13.7 & $0.259(0.013)$ & $5.6(0.4)$ & $-6.0(0.6)$ & $2.5(0.6)$ & $-7.0(0.8)$ & $1.0(1.0)$ \\
\hline \multirow[t]{8}{*}{ AESOPS II bag 1} & 0.0 & $0.060(0.003)$ & $15.1(0.9)$ & $0.2(0.4)$ & $-0.3(0.3)$ & $0.2(0.4)$ & $0.0(0.7)$ \\
\hline & 0.6 & - & - & $-0.2(0.6)$ & $0.3(0.4)$ & $-0.2(0.2)$ & $0.0(0.7)$ \\
\hline & 1.1 & $0.077(0.004)$ & $16.5(1.0)$ & $-0.8(0.5)$ & $0.7(0.3)$ & $-1.4(0.6)$ & $0.7(0.8)$ \\
\hline & 2.1 & $0.090(0.005)$ & $18.9(1.1)$ & $-1.8(0.6)$ & $1.5(0.4)$ & $-3.0(0.6)$ & $1.4(0.9)$ \\
\hline & 3.1 & $0.089(0.003)$ & $20.0(1.2)$ & $-3.6(1.0)$ & $2.0(0.4)$ & $-4.7(0.8)$ & $1.9(1.3)$ \\
\hline & 6.1 & $0.066(0.003)$ & $46.8(2.8)$ & $-4.7(0.8)$ & $4.5(0.4)$ & $-7.4(0.5)$ & $2.7(1.0)$ \\
\hline & 10.1 & $0.061(0.003)$ & $62.0(3.7)$ & $-5.5(0.4)$ & $5.8(0.4)$ & $-8.1(0.3)$ & $2.4(0.6)$ \\
\hline & 15.0 & $0.067(0.003)$ & $56.4(3.4)$ & $-8.0(0.5)$ & $8.2(0.5)$ & $-12.1(0.7)$ & $4.0(1.0)$ \\
\hline \multirow[t]{7}{*}{ AESOPS II bag 2} & 0 & $0.062(0.003)$ & $11.5(0.7)$ & $0.0(0.6)$ & $0.0(0.4)$ & $0.02(0.8)$ & $0.0(1.0)$ \\
\hline & 1 & $0.066(0.003)$ & $18.9(1.1)$ & $0.3(0.6)$ & $0.0(0.1)$ & $-0.2(0.3)$ & $0.4(0.7)$ \\
\hline & 2 & - & - & $-0.1(0.8)$ & $-0.2(0.3)$ & $0.2(0.7)$ & $-0.2(1.0)$ \\
\hline & 3 & $0.074(0.004)$ & $29.5(1.8)$ & $-0.3(0.8)$ & $0.2(0.1)$ & $-1.6(0.5)$ & $1.3(0.9)$ \\
\hline & 6 & $0.072(0.004)$ & $35.2(2.1)$ & $-1.0(0.6)$ & $0.1(0.1)$ & $-1.8(0.4)$ & $1.2(0.7)$ \\
\hline & 10 & $0.067(0.003)$ & $43.0(2.6)$ & $-1.7(0.5)$ & $1.6(0.5)$ & $-2.9(0.3)$ & $1.3(0.8)$ \\
\hline & 15 & $0.084(0.004)$ & $41.7(2.5)$ & $-3.2(0.9)$ & $3.1(0.1)$ & $-5(0.2)$ & $1.9(1.0)$ \\
\hline
\end{tabular}
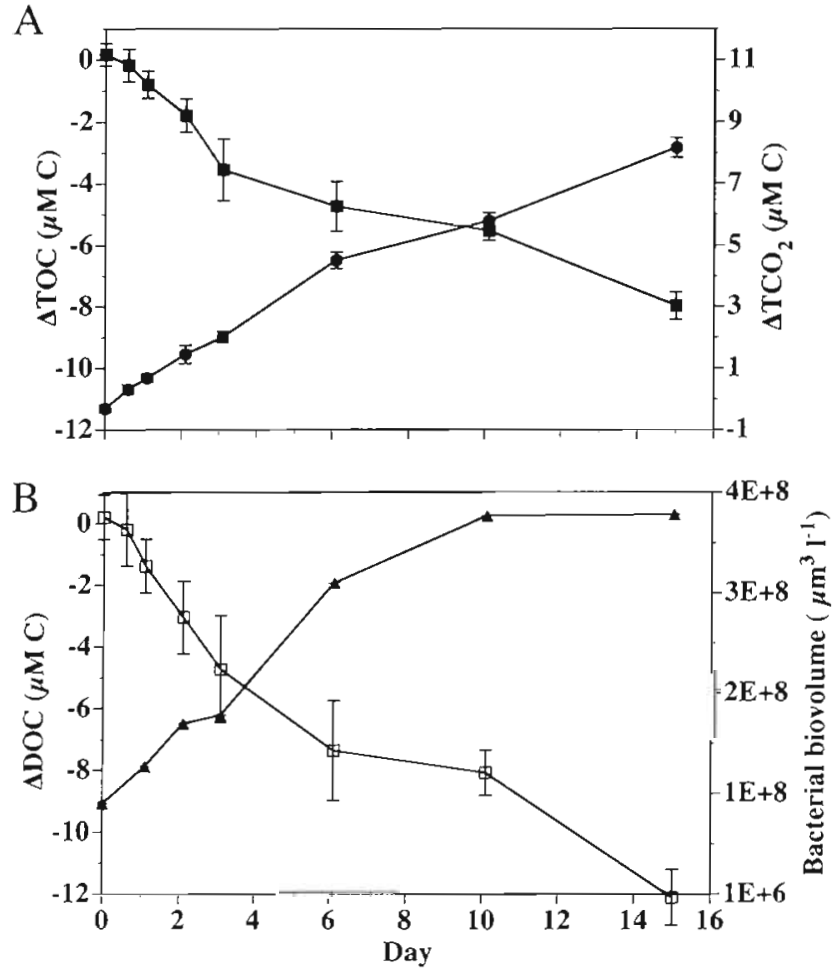

Fig. 3. AESOPS II bag 1 provides an example of time varying changes in $(\mathrm{A}) \triangle \mathrm{TOC}(\bullet)$ and $\triangle \mathrm{TCO}_{2}(\bullet)$ and $(\mathrm{B}) \triangle \mathrm{DOC}(\square)$ and bacterial biovolume ( $\Lambda$ ). Error bars represent standard error of mean but was calculated according to Eq. (2). The lack of reliable DOC measurements in the RSPP experiments prevented us from using mass balance to estimate $\triangle P O C$ for those experiments. However, AESOPS II experiments were unamended cultures where the measured TOC, $\mathrm{TCO}_{2}$ and DOC allowed for mass balance calculations of $\triangle \mathrm{POC}$ (Table 4, Fig. 4). We used

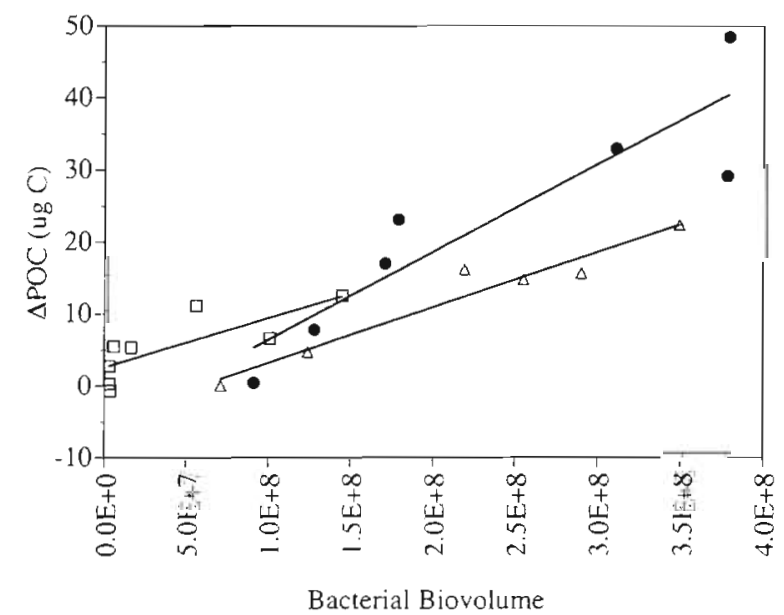

Fig. 4. Model II regression of $\triangle \mathrm{POC}(\mu \mathrm{g} \mathrm{C})$ versus bacterial

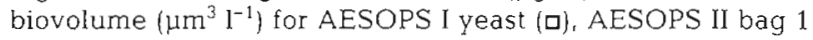
$(\bullet)$ and AESOPS II bag $2(\Delta)$. Lines represent the slope of the geometric mean regression (see text). The slopes of thesecurves represent a carbon conversion factor (see Table 4) 
Table 3. Bag experiments conducted during the RSPP, 1995. Values in parentheses are standard error

\begin{tabular}{|c|c|c|c|c|c|c|}
\hline Expt & Day & $\begin{array}{l}\text { Mean cell volume } \\
\qquad\left(\mu \mathrm{m}^{3}\right)\end{array}$ & $\begin{array}{c}\text { Cell abundance } \\
\left(10^{8} \text { cells } ~^{-1}\right)\end{array}$ & $\begin{array}{c}\triangle \mathrm{TOC} \\
(\mu \mathrm{MC})\end{array}$ & $\begin{array}{l}\triangle \mathrm{TCO}_{2} \\
(\mu \mathrm{MC})\end{array}$ & $\begin{array}{l}\triangle P O C \\
(\mu M C)\end{array}$ \\
\hline \multirow[t]{10}{*}{ RSPP bag 1} & 0 & $0.073(0.004)$ & $1.5(0.09)$ & $0.0(0.2)$ & $0.0(0.3)$ & $0.01(0.01)$ \\
\hline & 0.5 & $0.072(0.004)$ & $1.3(0.07)$ & $0.0(0.5)$ & - & $-0.01(0.01)$ \\
\hline & 1 & $0.070(0.003)$ & $1.9(0.1)$ & $-3.4(0.5)$ & $3.0(0.6)$ & $0.02(0.01)$ \\
\hline & 2 & $0.113(0.006)$ & $1.7(0.1)$ & $-4.1(0.8)$ & - & $0.08(0.01)$ \\
\hline & 3 & $0.117(0.006)$ & $1.6(0.09)$ & $-4.6(0.6)$ & $4.1(0.1)$ & $0.07(0.01)$ \\
\hline & 4 & $0.101(0.005)$ & $2.8(0.17)$ & $-4.8(0.2)$ & - & $0.16(0.02)$ \\
\hline & 5 & $0.065(0.003)$ & $6.3(0.38)$ & $-4.7(0.5)$ & - & $0.28(0.03)$ \\
\hline & 6 & $0.128(0.006)$ & $6.6(0.39)$ & $-5.3(0.5)$ & - & $0.66(0.06)$ \\
\hline & 9 & $0.057(0.003)$ & $13.0(0.72)$ & $-5.3(0.5)$ & - & $0.57(0.05)$ \\
\hline & 11 & $0.057(0.003)$ & $14.0(0.85)$ & $-5.6(0.2)$ & $5.7(0.3)$ & $0.63(0.06)$ \\
\hline \multirow[t]{10}{*}{ RSPP bag $12^{\circ} \mathrm{C}$} & 0 & $0.073(0.004)$ & $1.5(0.09)$ & $0.3(0.6)$ & $0.6(0.6)$ & $0.01(0.01)$ \\
\hline & 0.5 & $0.074(0.004)$ & $1.1(0.07)$ & $-0.2(0.9)$ & - & $-0.01(0.01)$ \\
\hline & 1 & $0.090(0.004)$ & $1.0(0.06)$ & $0.0(0.7)$ & $-0.6(1.0)$ & $0.00(0.01)$ \\
\hline & 2 & - & - & $-2.3(0.4)$ & - & - \\
\hline & 3 & $0.052(0.003)$ & $4.7(0.3)$ & - & $1.9(0.7)$ & $0.13(0.02)$ \\
\hline & 4 & $0.054(0.003)$ & $7.8(0.5)$ & $-2.9(0.6)$ & - & $0.29(0.03)$ \\
\hline & 5 & $0.057(0.003)$ & $10.4(0.6)$ & $-3.6(0.4)$ & - & $0.44(0.04)$ \\
\hline & 6 & $0.057(0.003)$ & $8.2(0.5)$ & $-5.3(0.6)$ & - & $0.32(0.03)$ \\
\hline & 9 & $0.049(0.002)$ & $17.4(1.0)$ & $-5.5(0.6)$ & - & $0.66(0.06)$ \\
\hline & 11 & $0.044(0.002)$ & $18.6(1.1)$ & $-5.4(0.8)$ & $5.3(0.7)$ & $0.64(0.06)$ \\
\hline \multirow[t]{10}{*}{ RSPP bag 2} & 0 & $0.078(0.004)$ & $1.6(0.1)$ & $-0.1(0.4)$ & $0.3(0.4)$ & $-0.01(0.01)$ \\
\hline & 1 & $0.060(0.003)$ & $2.5(0.2)$ & $0.1(0.7)$ & - & $0.01(0.02)$ \\
\hline & 2 & $0.110(0.006)$ & $2.5(0.2)$ & $0.0(0.1)$ & $-0.3(0.9)$ & $0.12(0.02)$ \\
\hline & 3 & $0.090(0.005)$ & $5.0(0.3)$ & - & - & $0.27(0.03)$ \\
\hline & 4 & $0.072(0.005)$ & $8.1(0.5)$ & $-0.9(0.5)$ & - & $0.39(0.04)$ \\
\hline & 5 & $0.072(0.004)$ & $11.8(0.7)$ & - & - & $0.63(0.06)$ \\
\hline & 6 & $0.077(0.004)$ & $12.0(0.7)$ & - & - & $0.69(0.06)$ \\
\hline & 7 & $0.116(0.006)$ & $12.3(0.7)$ & - & - & $1.14(0.10)$ \\
\hline & 9 & $0.091(0.005)$ & $14.0(0.8)$ & $-2.5(0.5)$ & $1.6(0.5)$ & $1.00(0.09)$ \\
\hline & 10 & $0.084(0.004)$ & $9.70(0.6)$ & $-3.7(0.4)$ & $3.9(0.3)$ & $0.60(0.06)$ \\
\hline \multirow[t]{8}{*}{ RSPP bag 4} & 0 & $0.101(0.005)$ & $0.5(0.03)$ & $-0.3(0.6)$ & $0.2(0.3)$ & $0.01(0.01)$ \\
\hline & 0.7 & $0.088(0.004)$ & $0.4(0.02)$ & - & - & $-0.01(0.01)$ \\
\hline & 1.7 & $0.139(0.007)$ & $0.3(0.02)$ & $0.3(0.7)$ & $-0.2(0.3)$ & $0.00(0.01)$ \\
\hline & 2.7 & $0.195(0.010)$ & $0.6(0.04)$ & $-1.2(0.7)$ & - & $0.07(0.01)$ \\
\hline & 3.7 & $0.182(0.009)$ & $1.6(0.1)$ & - & - & $0.23(0.02)$ \\
\hline & 4.7 & $0.107(0.005)$ & $4.9(0.3)$ & $-1.4(0.7)$ & $0.8(0.3)$ & $0.43(0.04)$ \\
\hline & 5.7 & $0.083(0.004)$ & $6.4(0.4)$ & $-1.9(0.6)$ & $1.3(0.4)$ & $0.43(0.04)$ \\
\hline & 7.6 & - & - & $-3.8(0.7)$ & $3.7(0.3)$ & \\
\hline
\end{tabular}

Model II geometric mean regression of $\triangle \mathrm{POC}$ versus bacterial biovolume to derive CCF. This approach allowed us to maximize the use of the data obtained in each experiment. The mean CCF of the AESOPS II

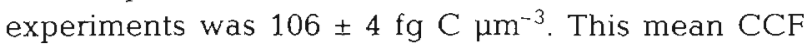
was then used to recover POC estimates from measurements of bacterial biovolumes for the RSPP bag experiments.

We did not include the CCF derived from the AESOPS I yeast experiment in the mean CCF to be applied to the RSPP experiments because it was from an amendment experiment and the changes in mean cell volume were as much as $4 \times$ greater than maximum cell volumes observed in other experiments (Table 2).

\section{Bacterial growth efficiency}

BGE could be determined independently of bacterial growth measurements in the AESOPS experiments where bacterial respiration and DOC concentrations were measured directly (Eqs. $3 \& 4$ ). Model II principal axis regression of $\triangle \mathrm{POC}$ versus $\triangle \mathrm{DOC}$ for each corresponding time point throughout each incubation provided estimates of BGE. This method of calculating BGE optimized the use of all data collected for AESOPS I yeast, and AESOPS II bag 1 and bag 2 experiments and yielded estimates of 12,32 and $38 \%$ respectively (Fig. 5A, Table 4).

For RSPP experiments, where direct measurements of DOC were not employed (see 'Methods'), bacterial 
Table 4. Bacterial growth efficiency (BGE) and carbon conversion factors (CCF) derived from Ross Sea bag experiments 1995-1997. Each conversion factor is determined by the slope of the Model II regression (see text) and values in parentheses represent standard error of the slope. The number of points used in the regression is signified as n. All slopes reported were significant at the 0.05 significance level

\begin{tabular}{lcrcccc}
\hline Expt & BGE & $\mathrm{n}$ & $\mathrm{r}^{2}$ & $\mathrm{CCF}\left(\mathrm{fg} \mathrm{C} \mu \mathrm{m}^{-3}\right)$ & $\mathrm{n}$ & $\mathrm{r}^{2}$ \\
\hline RSPP bag 1 & $0.09(0.03)^{\mathrm{a}}$ & 10 & 0.56 & - & - & - \\
RSPP bag 1 2 ${ }^{\circ} \mathrm{C}$ & $0.09(0.01)^{\mathrm{a}}$ & 9 & 0.86 & - & - & - \\
RSPP bag 2 & $0.19(0.06)^{\mathrm{a}}$ & 5 & 0.77 & - & - & - \\
RSPP bag 4 & $0.19(0.04)^{\mathrm{a}}$ & 5 & 0.80 & - & - & - \\
AESOPS I yeast & $0.12(0.03)$ & 7 & 0.76 & $95(24)$ & 7 & 0.69 \\
AESOPS II bag 1 & $0.32(0.02)$ & 7 & 0.95 & $134(26)$ & 6 & 0.83 \\
AESOPS II bag 2 & $0.38(0.06)$ & 7 & 0.84 & $77(9)$ & 6 & 0.94
\end{tabular}

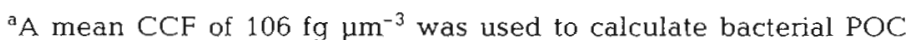
from measured biovolume. The $\triangle$ bacterial $P O C$ was then regressed against $\triangle \mathrm{BR}+\triangle \mathrm{POC}$ to derive $\mathrm{BGE}$ (see text) carbon production was calculated by multi-

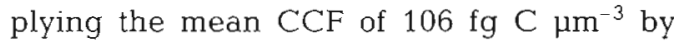
the bacterial biovolumes. These estimates of calculated $\triangle \mathrm{POC}$ were then regressed against $\triangle \mathrm{BR}+\triangle \mathrm{POC}$. The $B G E$ estimates for the RSPP bag experiments ranged from 9 to $19 \%$ (Fig. 5B, Table 4). The coefficient of determination was greater than 0.75 for all experiments except RSPP bag 1, which was 0.56 . There is an apparent shift in the slope of $\triangle \mathrm{POC}$ versus $\triangle \mathrm{BR}+\triangle \mathrm{POC}$, indicating the growth efficiency of the culture increased later in the experiment. As a result the BGE calculated from the whole time course tended to underestimate the $\mathrm{BGE}$ of the rapidly growing phase of the culture. This effect was less pronounced in other experiments.

\section{DISCUSSION}
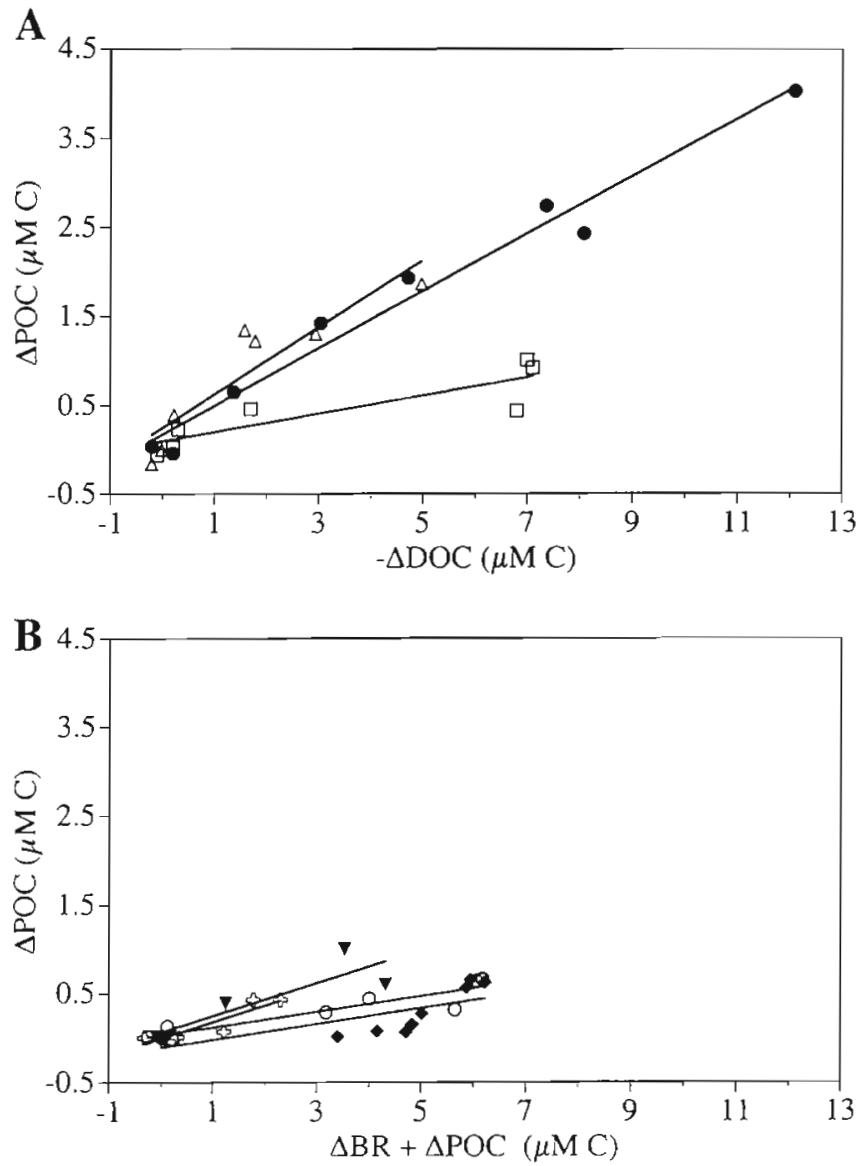

Fig. 5. Model II principal axis regression of $\triangle \mathrm{POC}(\mu \mathrm{MC})$ versus $\triangle D O C(\mu M C$ ) for (A) AESOPS I yeast (a), AESOPS II bag $1(\bullet)$ and AESOPS II bag $2(\Delta)$. (B) RSPP bag 1 ( $\bullet$ RSPP bag $12^{\circ} \mathrm{C}(0)$, RSPP bag $2(\nabla)$, and RSPP bag $3(\xi)$. The slope of the regression represents the bacterial growth efficiency (see Table 4)

\section{Assessment of experimental design}

Measuring BGE in natural systems continues to challenge microbial ecologists due to the shortcomings of current experimental designs. In a comprehensive review of bacterial growth efficiency del Giorgio \& Cole (1998) describe the advantages and disadvantages and associated problems of short- and long-term incubations in determining BGE. They suggest that short-term incubations should be more ecologically relevant; however, it is often not possible to measure changes in natural substrates on time scales of hours. The use of radiolabeled substrates (Hobbie \& Crawford 1969, Williams 1970,1981 ) allows for the detection of substrate changes with high sensitivity and minimizes incubation time but tends to overestimate BGE due to the use of model compounds. Alternatively, seawater culture techniques, which separate bacterioplankton from other components of the plankton community, allow microbial ecologists to assess bacterial dynamics (Kirchman et al. 1982, Ammerman et al. 1984, Simon \& Azam 1989, Bjørnsen \& Kuparinen 1991, Ducklow et al. 1992, 1998, Rivkin et al. 1996) and resolve changes in natural substrates or byproducts (Bjørnsen 1986b, Tranvik 1988, Servais et al. 1989, Coffin et al. 1993, Kroer 1993, Zweifel et al. 1993, Biddanda et al. 1994, Hansell et al. 1995, Carlson \& Ducklow 1996, Kähler et al. 1997), but require longer incubation, which can potentially introduce bottle effects. Potential artefacts associated with seawater cultures include passage of grazers through cut-off filters, wall growth (Kristiansen et al. 1992, Kruse 1993), viral infection (Proctor \& Fuhrman 1990, Wilcox \& Fuhrman 1994), forced use of more refractory DOM compounds as labile DOM is 
depleted (del Giorgio \& Cole 1998), production of toxic metabolic byproducts (Landwell \& Holme 1979) and the possibility of community structure shifts (Suzuki 1997. Carlson \& Giovannoni unpubl. data). As a result seawater cultures may produce bacterial dynamics not entirely representative of in situ dynamics and may lead to a lower BGE when longer incubations are conducted (del Giorgio \& Cole 1998 and references cited therein). However, in an extensive review of the literature (del Giorgio \& Cole 1998) did not find a systematic effect of long or short incubations on BGE estimates. Comparing some of the trends of bacterial dynamics observed in cultures to those observed in the field may provide insight as to whether our estimates of BGE and CCF are appropriate for in situ bacterioplankton.

The present study and those discussed in Ducklow et al, (1998) demonstrate that the Ross Sea seawater cultures required 1 to $2 \mathrm{wk}$ incubations for bacterioplankton to advance from lag to stationary phase and maximize the resolution of time varying changes in $\mathrm{TCO}_{2}$, TOC and DOC. One of the assumptions of this experimental design was that bacterioplankton and not higher trophic levels dominated the majority of the changes in chemical properties. Although $0.8 \mu \mathrm{m}$ pore size filters undoubtedly allow the passage of larger particles including potential grazers, there was little evidence of enhanced bacterivory present in these cultures. Microscopic examination did not reveal a large increase in bacteriovores during the study period (Ducklow et al. 1998). Ducklow et al. (1999) suggested that the rate of bacterial biomass production and the length of time which bacterial biomass continued to accumulate exponentially (up to $10 \mathrm{~d}$; their Tables 2 \& 3) indicate that top-down control was minimal in these Ross Sea seawater cultures. Field observations conducted in the same study area during austral spring 1994 demonstrated a 10-fold increase in bacterial production and up to a 5 -fold increase in bacterial biomass over the course of $19 \mathrm{~d}$ (Carlson et al. 1998), also indicating an uncoupling between bacterial production and bacterivory in the surface waters.

In the present study DOC concentrations were enhanced as a result of filtering large volumes of water with high POC concentrations (Table 1). We were concerned that the quality and quantity of the enhanced DOC might lead to a bacterial response uncharacteristic of those observed in situ. However, many of the observed bacterial parameters were comparable to those in situ. For example, specific growth rates determined from changes in cell abundance for these and other Ross Sea bacterial cultures (Ducklow et al. 1999) were not different from in situ specific growth rates calculated from bacterial production (measured by leucine incorporation with the conversion factor of Simon \& Azam 1989) and bacterial biomass estimates
(Ducklow et al. 1998). Mean cell volumes generally increased during our incubation and ranged from 0.052 to $0.195 \mathrm{\mu m}^{-3}$ (excluding 1 yeast-amended culture; Tables $2 \& 3$ ). These estimates are comparable to the range of in situ cell volume $\left(0.054\right.$ to $0.122{\mu \mathrm{m}^{3}}^{3})$ reported by Sherr et al. (1997) for a high-latitude Arctic system and to changes in cell volumes observed for the Ross Sea (US JGOFS AESOPS data set http://usjgofs.whoi.edu). In direct comparison of dark $0.8 \mu \mathrm{m}$ filtrates (DOC enhanced) to unfiltered water incubated in the light, Ducklow et al. (1999) found no differences between bacterial growth rates or changes in cell volumes over the same incubation periods. Bacterial growth response between $0.8 \mu \mathrm{m}$ and whole water cultures and field results were comparable, suggesting that DOC supplied via filtration may have been similar to the suite of DOM compounds supplied by natural whole water plankton communities.

The contribution of attached bacteria to the changes in chemical properties could confound estimates of $\mathrm{BGE}$ and CCF for free living bacterioplankton. Kruse (1993) reported significant colonization of the inner wall of bags by bacteria after 2 wk incubations at 5 and $12^{\circ} \mathrm{C}$. Colonization of bacteria on the inner walls of our bags did occur; however the contribution to the total number of bacteria in the bag was only a few percent of the total bacterial population. Pomeroy et al. (1991) also found attached bacteria to be insignificant relative to the total biomass in long-term cold water $\left(<2^{\circ} \mathrm{C}\right)$ culture experiments. We do not have estimates of activity associated with the attached bacteria but assume, based on numbers, that the contribution of attached bacteria was minimal in our experiments.

It must be noted that viral abundance and interaction with bacterioplankton were not accounted for during the present study. Viruses have been shown to be ubiquitous in marine systems (Bergh et al. 1989, Proctor \& Fuhrman 1990, Cochlan et al. 1993, Fuhrman \& Noble 1995). Middelboe et al. (1997) found that BGE of bacterioplankton decreased in the presence of viruses.

The bacterial growth parameters observed in the seawater cultures were characteristic of bacterial parameters observed in the water column of the southern Ross Sea. However taxonomic diversity was not assessed in these experiments, thus we cannot rule out the possibiliby that there was a taxonomic shift in the community structure of bacterioplankton during incubation (Suzuki 1997, Carlson \& Giovannoni unpubl. data).

We caution that artefacts such as the possible removal of bacterial biomass via grazing or viral infection, remineralization by attached bacteria and forced consumption of more refractory compounds may all underestimate true BGE for the assemblages growing in the seawater cultures. Molecular techniques have demonstrated a great diversity of bacterioplankton in 
natural systems (Giovannoni et al. 1990, 1996, DeLong et al. 1993, Fuhrman et al. 1993), of which some subpopulations may be actively growing and others dormant (del Giorgio et al. 1997b, Karner \& Fuhrman 1997. Smith 1998). If seawater cultures favor the development of an active population the resulting BGE may be higher than characteristic of in situ assemblages (del Giorgio \& Cole 1998). Further work is needed to assess the relative pool size of active and inactive bacterial pools and the role each plays in carbon cycling.

\section{Conversion factors}

Empirical CCFs were determined for experiments where a full suite of TOC, DOC, and $\mathrm{TCO}_{2}$ measurements were conducted (Fig. 4). The unamended AESOPS II cultures were used to derive a mean CCF, which would subsequently be used to calculate $\triangle \mathrm{POC}$ from biovolume for the RSPP experiments. The magnitude of the initial cell concentration and subsequent change in cell abundance were greater in AESOPS II than for all other experiments. However the range of mean cell volume observed in these experiments $(0.060$ to 0.090$)$ were within the range of the RSPP experiments (Table 3 ) and in situ observations for the Ross Sea and other high-latitude systems (Sherr et al. 1997). The similarity in cell size indicates that it is appropriate to apply CCF derived from AESOPS II experiments to earlier RSPP experiments.

The regression of calculated $\triangle \mathrm{POC}$ versus biovolume yielded CCF values significantly lower than those determined in other Southern Ocean systems (Table 5). However, a 9-fold range of CCF exists in the literature, from low values of 63 to $86 \mathrm{fg} \mathrm{C} \mathrm{m}{ }^{-3}$ (Ferguson \& Rublee 1976, Nagata \& Watanabe 1990, Fagerbakke et

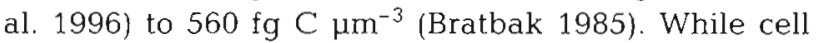
volumes observed in the Ross Sea (both field and experimental work) were larger than those observed in tropical and subtropical systems (Ducklow et al. 1998), the mean CCF determined for these cells was similar to that determined for the oligotrophic Sargasso Sea (Gundersen et al. 1994) and are comparable to the commonly cited value of $121 \mathrm{fg} \mathrm{C} \mathrm{mm}^{-3}$ (Watson et al.

Table 5. Empirically derived carbon conversion factors (CCF) and bacterial growth efficiencies (BGE) from Antarctic habitats

\begin{tabular}{|llcc|}
\hline Expt & Location & CCF (fg C $\mu m^{-3}$ ) & BGE \\
\hline Bjørnsen \& Kuparinen (1991) & Weddell Sea & 450 & 0.40 \\
Bjørnsen \& Kuparinen (1991) & Weddell/Scotia Confluence & 370 & - \\
Bjørnsen \& Kuparinen (1991) & Scotia Sea & 350 & 0.38 \\
Kähler et al. (1997) & Antarctic Polar Front & $260-280$ & $0.26-0.30$ \\
This study & Ross Sea & $77-134$ & $0.09-0.38$ \\
\hline
\end{tabular}

1977. Nagata \& Watanabe 1990; also see review by Ducklow \& Carlson 1992). Bjørnsen \& Kuparinen (1991) correctly point out that the large variability of CCF may be due to subjectivity of visual cell sizing and stresses the need for more intercalibration exercises. Joint \& Pomroy (1987) point out that the larger values of $\mathrm{CCF}$ are difficult to reconcile with bacterial physiology and composition.

BGE was estimated by linear regression of $\triangle \mathrm{POC}$ versus $\triangle \mathrm{DOC}$. For the AESOPS experiments, where $\triangle \mathrm{POC}$ was estimated via carbon mass balance, $B G E$ ranged from 12 to $38 \%$. For the RSPP experiments, where $\triangle \mathrm{POC}$ was calculated from $\mathrm{CCF}$ and biovolume estimates, BGE ranged from 9 to $19 \%$. Estimates from the 2 approaches demonstrated an overlapping range of BGE, indicating that neither method systematically produced high or low growth yield estimates. Our high-end determinations of BGE are comparable to other estimates reported from the Southern Ocean (Table 5). They are also similar to conversion factors derived from subtropical eutrophic systems (Coffin et al. 1993, Biddanda et al. 1994). Our low-end estimates of BGE are outside the range of previous Southern Ocean studies (Table 5) and are comparable to values found in the oligotrophic Sargasso Sea (Carlson \& Ducklow 1996). Similar BGE variability can be found in temperate and subtropical systems (Jahnke \& Craven 1995, Carlson \& Ducklow 1996, del Giorgio \& Cole 1998). In a cross system literature survey, del Giorgio and colleagues (del Giorgio et al. 1997a, del Giorgio \& Cole 1998) found that BGE estimates for most freshwater and marine systems ranged from less than $10 \%$ to approximately $25 \%$.

BGE estimated from the present study increased as phytoplankton blooms proceeded from early spring (RSPP bag 1 and bag 2) to late summer (AESOPS II bag 1 and bag 2; Table 4). These results are consistent with observations of increased BGE along a gradient of productivity (del Giorgio \& Cole 1998). Quantity and quality of available organic material along with the availability of inorganic nutrients are thought to play an important role in regulating BGE (del Giorgio \& Cole 1998). Surprisingly, we observed one of the lowest BGEs for the AESOPS I yeast experiment (a high quality substrate) in the presence of elevated macronutrients, indicating that substrate quality alone does not dictate BGE. One possible explanation was that the physiological state or the taxonomic make-up of the late winter/early spring bacterioplankton assemblage required more maintenance energy to shift to cell growth stage (note the long lag phase; Table 2). 
Further work with regard to taxonomic diversity and shifts in population physiology is required to address this question.

\section{Consequence of systematic error}

Systematic errors in the experimental protocol can also lead to inaccurate estimates of CCF and BGE. We know of at least 2 types of systematic error, which are not accounted for in these analyses. The first type of systematic error, $\alpha$, is the fraction of POC (primarily bacterial biomass) recycled or respired during the incubation period. Processes of such cell maintenance, viral lysis of bacterial cells and subsequent use of the released DOM (Proctor \& Fuhrman 1990, Fuhrman 1992, Middelboe et al. 1997) or microbial hydrolysis of particles (Smith et al. 1992) would be responsible for $\alpha$. The systematic error of $\alpha$ would result in an underestimate of $\triangle \mathrm{POC}$, and would, thus, lead to an underestimate of BGE. To account for $\alpha$, Eq. (3) would be rewritten as:

$$
\mathrm{BGE}=\frac{\Delta \mathrm{POC} \times(1+\alpha)}{(\Delta \mathrm{BR}-\Delta \mathrm{POC} \times \alpha)+[\Delta \mathrm{POC} \times(1+\alpha)]}
$$

or

$$
\mathrm{BGE}=\frac{\triangle \mathrm{POC} \times(1+\alpha)}{-\triangle \mathrm{DOC}}
$$

The second type of systematic error, $\beta$, is the fraction of the POC pool which passes through the GF/F filter (Altabet 1990). This type of error underestimates $\triangle D O C$ and underestimates $\triangle \mathrm{POC}$. To account for $\beta$, Eq. (3) would be rewritten as

$$
\mathrm{BGE}=\frac{\Delta \mathrm{POC}}{-\triangle \mathrm{DOC} \times(1-\beta)+\triangle \mathrm{POC} \times \beta}
$$

or by inserting Eq. (6) into Eq. (7),

$$
\mathrm{BGE}=\frac{\Delta \mathrm{POC} \times(1+\alpha)}{-\Delta \mathrm{DOC} \times(1-\beta)+\Delta \mathrm{POC} \times(1+\alpha)(\beta)}
$$

The consequence of not accounting for these error terms is an underestimation of BGE and CCF. We were not able to estimate $\alpha$ directly from our data set. If, for example, $\alpha$ and $\beta$ were estimated to be 0.05 and 0.15 , respectively, the recalculated range of $\mathrm{BGE}$ and $\mathrm{CCF}$ would then slightly higher our calculation (Table 6). These error terms are important to account for if possible.

\section{Implications of BGE towards carbon cycling}

The amount of carbon needed to support bacterial production is called bacterial carbon demand (BCD). $\mathrm{BCD}$ is usually calculated by dividing estimates of bac- terial carbon production by BGE. Low BGEs have vast implications for the biogeochemistry of aquatic systems (Kirchman 1997). For example a lower BGE requires a larger flux of carbon to support observed bacterial production than a higher BGE. The lower BGE determined for natural assemblages of bacterioplankton grown on natural substrates can result in BCD exceeding phytoplankton production even in unproductive systems (Hansell et al. 1995, Carlson \& Ducklow 1996, Sherr \& Sherr 1996, del Giorgio et al. 1997a). An overestimation of BGE will ultimately lead to an underestimation of the carbon flux through bacterioplankton and thus BGE and/or bacterial respiration are important parameters to constrain (Jahnke \& Craven 1995).

The BGE determined here can be applied to in situ estimates of bacterial production in order to calculate $\mathrm{BCD}$. The integrated BCD of the south central Ross Sea has been reported to be approximately $10 \%$ of primary production when calculated with a BGE $<20 \%$ (Carlson et al. 1998). These findings are consistent with previous observations in Antarctic ecosystems, which suggest a fundamental uncoupling of primary production and bacterial production (Cota et al. 1990, Karl et al. 1991, Karl \& Bird 1993). Pomeroy and colleagues (Pomeroy \& Deibel 1986, Pomeroy et al. 1990, 1991) have hypothesized that low temperatures $\left(-2\right.$ to $\left.0^{\circ} \mathrm{C}\right)$ may limit bacterial growth even in the presence of a spring phytoplankton bloom. However, several subsequent studies have demonstrated that bacterial growth rates in cold water climates span the range observed in other lower latitude systems (Karl 1993, Cota et al. 1996, Rivkin et al. 1996, Rich et al. 1997, Carlson et al. 1998, Ducklow et al. 1998) and may be growing at near-maximal rates. Karl et al. (1991) and Carlson et al. 
(1998) have hypothesized that substrate supply and not temperature may limit bacterial production in some regions of the Southern Ocean. In this study, we used gas impermeable tri-laminate bags in combination with direct measurements of substrate utilization, bacterial respiration and bacterial growth to constrain carbon mass balance in Ross Sea seawater cultures. The ultimate objective of this work was to generate estimates of BGE and CCF, which could be applied to in situ measurements of bacterial growth for the Ross Sea polynya. This experimental design could be further expanded to include $\mathrm{O}_{2}$ consumption measurements. The combination of $\mathrm{TCO}_{2}$ and $\mathrm{O}_{2}$ measurements from the same incubation bag would provide much needed estimates of RQs. This carbon mass balance approach could be applied to other aquatic systems to empirically derive the $\mathrm{BGE}$ and $\mathrm{CCF}$, factors essential for determining carbon flux through bacterioplankton.

Acknowledgements. We gratefully acknowledge the dedicated support extended by Captain Borkowski and the officers and crew of RVIB 'Nathaniel B. Palmer' and by Antarctic Support Associates. We are grateful to W. O. Smith for providing in situ chl $a$ and POC values used in Table 1. We thank A. Bryant-Sanford, M. Church, F. Cunningham, R. Parsons, F. Howse, D. Kirchman, A. Ritchie, D. Smith, and T. Tredennick for assistance in setting up experiments and collecting samples, and D. Karl, P. J. le B Williams, and 1 anonymous reviewer for constructive comments on this manuscript. Expert technical assistance was provided by Helen Quinby. This work was supported by NSF Grants OCE 94-16565 to N.R.B., OPP 93-17200 to D.A.H., OCE 9530845 to D.A.H and C.A.C., and OPP 93-19222 and OCE 93-19222 to H.W.D. This is BBSR contribution no. 1541 and US JGOFS contribution no. 469.

\section{LITERATURE CITED}

Altabet MA (1990) Organic C, N, and stable isotopic composition of particulate matter collected on glass-fiber and aluminum oxide filters. Limnol Oceanogr 35:902-909

Ammerman JW, Fuhrman JA, Hagstrom A, Azam F (1984) Bacterioplankton growth in seawater: I. Growth kinetics and cellular characteristics in seawater cultures. Mar Ecol Prog Ser 18:31-39

Azam F, Hodson RE (1977) Size distribution and activity of marine microheterotrophs. Limnol Oceanogr 22:492-501

Bates NR, Michaels AF, Knap AH (1996) Seasonal and interannual variability of the oceanic carbon dioxide system at the U.S. JGOFS Bermuda Atlantic Time-series Site. DeepSea Res II 43:347-383

Bauer JE, Williams PM, Druffel ERM (1992) ${ }^{14} \mathrm{C}$ activity of dissolved organic carbon fractions in the north-central Pacific and Sargasso Sea. Nature 357:667-670

Benner, Lay J, K'nees E, Hodson RE (1988) Carbon conversion efficiency for bacterial growth on lignocellulose: implications for detritus-based foodwebs. Limnol Oceanogr 33 $1514-1526$

Bergh Ø, Børsheim KY, Bratbak G, Heldal M (1989) High abundance of viruses found in aquatic environments. Nature 340:467-468
Bevington PR (1969) Data reduction and error analysis for the physical sciences. McGraw-Hill, New York

Biddanda B, Opsahl S, Benner R (1994) Plankton respiration and carbon flux through bacterioplankton on the Louisiana shelf. Limnol Oceanogr 39:1259-1275

Bjørnsen PK (1986a) Automatic determination of bacterioplankton biomass by image analysis. Appl Environ Microbiol 51:1199-1204

Bjørnsen PK (1986b) Bacterioplankton growth yield in continuous seawater cultures. Mar Ecol Prog Ser 30:191-196

Bjørnsen PK, Kuparinen J (1991) Determination of bacterioplankton biomass, net production and growth efficiency in the Southern Ocean. Mar Ecol Prog Ser 71:185-194

Bratbak G (1985) Bacterial volume and biomass estimations. Appl Environ Microbiol 49:1488-1493

Carlson CA, Ducklow HW (1995) Dissolved organic carbon in the upper ocean of the central Equatorial Pacific, 1992: daily and finescale vertical variations. Deep-Sea Res II 42:639-656

Carlson CA, Ducklow HW (1996) Growth of bacterioplankton and consumption of dissolved organic carbon in the Sargasso Sea. Aquat Microb Ecol 10:69-85

Carlson CA, Ducklow HW, Hansell DA, Smith WO (1998) Organic carbon partitioning during spring phytoplankton blooms in the Ross Sea Polynya and the Sargasso Sea. Limnol Oceanogr 43:375-386

Carlson CA, Hansell DA, Smith WO (1998b) Filtration volume and retention of particulate organic carbon on GF/F filters during a Phaeocystis antarctica bloom in the Ross Sea, Antarctica. Antarct J US (in press)

Cherrier J, Bauer JE, Druffel ERM (1996) Utilization and turnover of labile dissolved organic matter by bacterial heterotrophs in eastern North Pacific surface waters. Mar Ecol Prog Ser 139:267-279

Cochlan WP, Wikner J, Steward GF, Smith DC, Azam F (1993) Spatial distribution of viruses, bacteria and chlorophyll a in neritic, oceanic and estuarine environments. Mar Ecol Prog Ser 92:77-87

Coffin RB, Connolly JP, Harris PS (1993) Availability of dissolved organic carbon to bacterioplankton examined by oxygen utilization. Mar Ecol Prog Ser 101:9-22

Cota GF, Kottmeier ST, Robinson DH, Smith WO, Sullivan CW (1990) Bacterioplankton in the marginal ice zone of the Weddell Sea: biomass, production and metabolic activities during austral autumn. Deep-Sea Res I 37: $1145-1167$

Cota GF, Pomeroy LR, Harrison WG, Jones EP, Peters F, Sheldon WM, Weingartner TR (1996) Nutrient, primary production and microbial heterotrophy in the southeastern Chuckchi Sea: Arctic summer nutrient depletion and heterotrophy. Mar Ecol Prog Ser 135:247-258

Daneri G, Riemann B, Williams PJleB (1994) In situ bacterial production and growth yield measured by thymidine. leucine and fractionated dark oxygen uptake. J Plankton Res 16:105-113

del Giorgio PA, Cole JJ (1998) Bacterial growth efficiency in natural aquatic systems. Annu Rev Ecol Syst 29:503-54 1

del Giorgio PA, Cole JJ, Cibleris A (1997a) Respiration rates in bacteria exceed phytoplankton production in unproductive aquatic systems. Nature 385:148-151

del Giorgio PA, Prairie YT, Bird DF (1997b) Coupling between rates of bacterial production and the abundance of metabolically active bacteria in lakes, enumerated using CTC reduction and flow cytometry. Microb Ecol 34:144-145

DeLong EF, Franks DG, Alldredge AL (1993) Phylogenetic diversity of aggregate-attached vs. free-living marine bacterial assemblages. Limnol Oceanogr 38:924-934 
Ducklow HW, Carlson CA (1992) Oceanic bacterial production. Adv Microb Ecol 12:113-181

Ducklow HW, Shiah F (1993) Bacterial production in estuaries. Aquatic microbiology: an ecological approach. Blackwell Science, Cambridge, MA, p 261-288

Ducklow HW, Kirchman DL, Quinby HL (1992) Bacterioplankton cell growth and macromolecular synthesis in seawater cultures during the North Atlantic Bloom spring phytoplankton bloom, May 1989. Microb Ecol 24: $125-144$

Ducklow HW, Quinby HL, Church M, Sanford AL (1998) Bacterioplankton response to the Phaeocystis bloom in the Ross Sea Polynya, November, 1994-January, 1996. EOS 79:171

Ducklow HW, Carlson CA, Smith WO (1999) Bacterial growth in experimental plankton assemblages and seawater cultures from the Phaeocystis antarctica bloom in the Ross Sea, Antarctica. Aquat Microb Ecol 19:215-227

Fagerbakke KM, Heldal M, Norland S (1996) Content of carbon, nitrogen, oxygen sulfur and phosphorus in native and aquatic cultured bacteria. Aquat Microb Ecol 10:15-27

Ferguson RL, Rublee P (1976) Contribution of bacteria to standing crop of coastal plankton. Limnol Oceanogr 22: $141-145$

Fitzwater SE, Knauer GA, Martin JH (1982) Metal contamination and its effect on primary production measurements. Limnol Oceanogr 27:544-551

Fuhrman JA (1992) Bacterioplankton roles in cycling of organic matter: the microbial food web. Primary productivity and biogeochemical cycles in the sea. Plenum Press, New York, p 361-383

Fuhrman JA, Noble RT (1995) Viruses and protist cause similar bacterial mortality in coastal seawater. Limnol Oceanogr 40:1236-1242

Fuhrman JA, Ammerman JW, Azam F (1980) Bacterioplankton in the coastal euphotic zone: distribution, activity and possible relationships with phytoplankton. Mar Biol 60:201-207

Fuhrman JA, McCallum K, Davis AA (1993) Phylogenetic diversity of subsurface marine microbial communities from the Atlantic and Pacific oceans. Appl Environ Microbiol 59:1294-1302

Giovannoni SJ, Britschgi TB, Moyer CL, Field KG (1990) Genetic diversity in Sargasso Sea bacterioplankton Nature 345:60-63

Giovannoni SJ, Rappé MS, Vergin K, Adair N (1996) 16S rRNA genes reveal stratified open ocean bacterioplankton populations related to the green non-sulfur bacteria phylum. Proc Natl Acad Sci USA 93:7979-7984

Gundersen K, Heldal M, Norland S (1994) Single cell bacterial carbon and nitrogen in the Sargasso Sea. EOS 75:100

Hansell DA, Waterhouse TY (1996) Controls on the meridional distribution of total organic carbon and nitrogen in the eastern South Pacific Ocean. Deep-Sea Res I 44: 843-857

Hansell DA, Bates NR, Gundersen K (1995) Mineralization of dissolved organic carbon in the Sargasso Sea. Mar Chem 51:201-212

Hobbie JE, Crawford CC (1969) Respiration correction for bacterial uptake of dissolved organic compounds in natural waters. Limnol Oceanogr 14:528-533

Hobbie JE, Daley RJ, Jasper S (1977) Use of Nuclepore filters for counting bacteria by epifluorescence microscopy. Appl Environ Microbiol 33:1225-1228

Jahnke R, Craven DB (1995) Quantifying the role of heterotrophic bacteria in the carbon cycle: a need for respiration rate measurements. Limnol Oceanogr 40:436-441
Jensen LM, Sand-Jensen K, Marcher S, Hansen M (1990) Plankton community respiration along a nutrient gradient in a shallow Danish estuary. Mar Ecol Prog Ser 61:75-85

Johnson KM, King AE, Sieburth JM (1985) Coulometric $\mathrm{TCO}_{2}$ analyses for marine studies: an introduction. Mar Chem $16: 61-92$

Johnson KM, Sieburth JM, Williams PJleB, Brandstrom L (1987) Coulometric total carbon dioxide analysis for marine studies: automation and calibration. Mar Chem $21: 117-133$

Johnson KM, Wills KD, Butler DB, Johnson WK, Wong CS (1993) Coulometric total carbon dioxide analysis for marine studies: maximizing the performance of an automated gas extraction system and coulometric detector Mar Chem 44:167-188

Joint IR, Pomeroy AJ (1987) Activity of heterotrophic bacteria in the euphotic zone of the Celtic Sea. Mar Ecol Prog Ser 41:155-165

Kähler P, Bjørnsen PK, Lochte K, Anita A (1997) Dissolved organic matter and its utilization by bacteria during spring in the Southern Ocean. Deep-Sea Res II 44:341-353

Karl DM (1979) Measurements of microbial activity and growth in the ocean by rates of stable ribonucleic acid synthesis. Appl Environ Microbiol 38:850-860

Karl DM (1993) Microbial processes in the Southern Ocean Antarctic microbiology. Wiley-Liss, New York, p 1-63

Karl DM, Bird DF (1993) Bacterial-algal interaction in Antarctic coastal ecosystems. Trends in microbial ecology. Spanish Society of Microbiology, Barcelona, p 37-40

Karl DM, Holm-Hansen O, Taylor GT, Tien G, Bird DF (1991) Microbial biomass and productivity in the western Bransfield Strait, Antarctica, during the 1986-87 austral summer. Deep-Sea Res I 38:1029-1055

Karner M, Fuhrman JA (1997) Determination of active marine bacterioplankton: a comparison of universal 16S IRNA probes, autoradiography, and nucleoid staining. Appl Environ Microbiol 63:1208-1213

Kirchman DL (1997) Microbial breathing lessons. Nature 385:121-122

Kirchman D, Ducklow H, Mitchell R (1982) Estimates of bacterial growth from changes in uptake rates and biomass. Appl Environ Microbiol 44:1296-1307

Kirchman DL, K'nees E, Hodson RE (1985) Leucine incorporation and its potential as a measure of protein synthesis by bacteria in natural aquatic systems. Appl Environ Microbiol 49:599-607

Kirchman DL, Suzuki Y, Garside C, Ducklow HW (1991) High turnover rates of dissolved organic carbon during a spring phytoplankton bloom. Nature 352:612-614

Kirchman DL, Lancelot C, Fasham M, Legendre L, Radach G, Scott M (1993) Dissolved organic matter in biogeochemical models of the ocean. Towards a model of ocean biogeochemical processes. Springer-Verlag, Berlin, p 209-225

Kristiansen K, Nielsen H, Riemann B, Fuhrman JA (1992) Growth efficiencies of freshwater bacterioplankton. Microbial Ecol 24:145-167

Kroer N (1993) Bacterial growth efficiency on natural dissolved organic matter. Limnol Oceanogr 38:1282-1290

Kruse B (1993) Measurement of plankton $\mathrm{O}_{2}$ respiration in gas-tight plastic bags. Mar Ecol Prog Ser 94:155-163

Lampert W (1978) Release of dissolved organic carbon by grazing zooplankton. Limnol Oceanogr 23:831-834

Landwell P, Holme $T$ (1979) Removal of inhibitors of bacterial growth by dialysis culture. J Gen Microbiol 103:345-352

Middelboe M, Jørgensen NOG, Kroer N (1997) Effect of viruses on nutrient turnover and growth efficiency of noninfected marine bacterioplankton. Appl Environ Microbiol 
$62: 1991-1997$

Nagata T, Watanabe Y (1990) Carbon and nitrogen to volume ratios of bacterioplankton grown under different nutritional conditions. Appl Environ Microbiol 56:1303-1309

Newell RC, Lucas MI, Linley EAS (1981) Rate of degradation and efficiency of conversion of phytoplankton debris by marine micro-organisms. Mar Ecol Prog Ser 6:123-136

Pomeroy LR, Deibel D (1986) Temperature regulation of bacterial activity during the spring bloom in Newfoundland coastal waters. Science 233:359-361

Pomeroy LR, Macko SA, Ostrom PH, Dunphy J (1990) The microbial food web in Arctic seawater: concentration of dissolved free amino acids and bacterial abundance and activity in the Arctic Ocean and in Resolute passage. Mar Microb Food Webs 61:31-40

Pomeroy LR, Wiebe WJ, Deibel D, Thompson RJ, Rowe GR Pakulski JD (1991) Bacterial response to temperature and substrate concentrations during the Newfoundland spring bloom. Mar Ecol Prog Ser 75:143-159

Proctor LM, Fuhrman JA (1990) Viral mortality of marine bacteria and cyanobacteria. Nature 343:60-62

Rich JH, Ducklow HW, Kirchman DL (1996) Concentration and uptake of neutral monosaccharides along $140^{\circ} \mathrm{W}$ in the equatorial Pacific: contribution of glucose to heterotrophic bacterial activity and the DOM flux. Limnol Oceanogr 41:595-604

Rich J, Gosselin M, Sherr E, Sherr B, Kirchman DL (1997) High bacterial production, uptake and concentrations of dissolved organic matter in the Central Arctic Ocean. Deep-Sea Res II 44:1645-1663

Rivkin RB, Anderson MR, Lajzerowicz C (1996) Microbial processes in cold oceans. I. Relationship between temperature and bacterial growth rate. Aquat Microb Ecol 10: 243-254

Servais P, Anzil A, Ventresque C (1989) Simple method for determination of biodegradable dissolved organic carbon in water. Appl Environ Microbiol 55:2732-2734

Sharp JH (1994) The broad community DOC methods comparison. EOS 75:106

Sherr EB, Sherr BE (1996) Temporal offset in oceanic production and respiration processes implied by seasonal changes in atmospheric oxygen: the role of heterotrophic microbes. Aquat Microb Ecol 11:91-100

Sherr EB, Sherr BF, Fessenden L (1997) Heterotrophic protists in the Central Arctic Ocean. Deep-Sea Res II 44:1665-1682

Editorial responsibility: David Karl,

Honolulu, Hawaii, USA
Simon M, Azam F (1989) Protein content and protein synthesis rates of planktonic marine bacteria. Mar Ecol Prog Ser $51: 201-213$

Smith D, Simon M, Alldredge AL, Azam F (1992) Intense hydrolytic enzyme activity on marine aggregates and implications for rapid particle dissolution. Nature 359 $139-142$

Smith EM (1998) Coherence of microbial respiration rate and cell-specific bacterial activity in a coastal planktonic community. Aquat Microb Ecol 16:27-35

Smith EM, Kemp WM (1995) Seasonal and regional variations in plankton community production and respiration for Chesapeake Bay. Mar Ecol Prog Ser 116:217-231

Sokal RR, Rohlf FJ (1995) Biometry. WH Freeman \& Co, New York

Suzuki M (1997) The effect of protistan bacterivory on bacterioplankton community structure. PhD dissertation, Oregon State University, Corvallis

Tranvik LJ (1988) Availability of dissolved organic carbon for planktonic bacteria in oligotrophic lakes of differing humic content. Microbial Ecol 16:311-322

UNESCO (1994) Protocols for the Joint Global Ocean Flux Study (JGOFS) core measurements. Intergovernmental Oceanographic Commission, Washington, DC

Watson SW, Novitsky TJ, Quinby HL, Valois FW (1977) Determination of bacterial number and biomass in the marine environment. Appl Environ Microbiol 33:940-946

Wilcox RM, Fuhrman JA (1994) Bacterial viruses in coastal seawater: lytic rather than lysogenic production. Mar Ecol Prog Ser 114:35-45

Wilke R, Wallace DWR, Johnson KM (1993) A water-based, gravimetric method for determination of gas sampling loop volume. Anal Chem 65:2403-2406

Williams PJleB (1970) Heterotrophic utilization of dissolved organic compound in the sea. I. Size distribution of population and relationship between respiration and incorporation of growth substrates. J Mar Biol Assoc UK 50:859-870

Williams PJleB (1981) Incorporation of microheterotrophic processes into the classical paradigm of the planktonic food web. Kiel Meeresforsch 5:1-28

Williams PJleB (1984) A review of measurements of respiration rates of marine plankton populations. Heterotrophic activity in the sea. Plenum Press, New York, p 357-389

Zweifel UL, Norrman B, Hagström $\AA$ (1993) Consumption of dissolved organic carbon by marine bacteria and demand

Submitted: June 2, 1998; Accepted: December 28, 1998

Proofs received from author(s): October 11, 1999 